CERE Working Paper, 2021:3

\title{
Governance of urban green spaces across Latin America -Insights from semi-structured interviews to managers amid COVID-19
}

\author{
Jaime Sainz-Santamaria and Adan L. Martinez-Cruz
}

The Centre for Environmental and Resource Economics (CERE) is an inter-disciplinary and inter-university research centre at the Umeå Campus: Umeå University and the Swedish University of Agricultural Sciences. The main objectives with the Centre are to tie together research groups at the different departments and universities; provide seminars and workshops within the field of environmental \& resource economics and management; and constitute a platform for a creative and strong research environment within the field.

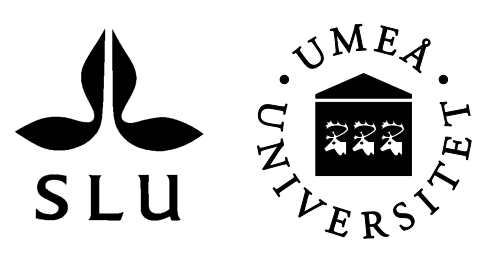




\title{
Governance of urban green spaces across Latin America - Insights from semi-structured interviews to managers amid COVID-19
}

\author{
Jaime Sainz-Santamaria ${ }^{a, *}$ \\ ${ }^{a}$ Department of Public Administration \\ Centro de Investigacion y Docencia Economicas (CIDE), Mexico \\ jaime.sainz@cide.edu \\ * Corresponding author \\ Adan L. Martinez-Cruz ${ }^{b}$ \\ ${ }^{b}$ Department of Forest Economics and \\ Centre for Environmental and Resource Economics (CERE), \\ Swedish University of Agricultural Sciences (SLU), Sweden \\ adan.martinez.cruz@slu.se
}

February 8, 2021

\begin{abstract}
The COVID-19 pandemic has brought unprecedented challenges to managers of urban green spaces. As suggested by findings from 18 structured interviews from six Latin American countries reported in this paper, managers in Latin America have not been able to take the most advantage of available green space during the COVID-19 lockdown. At the core of this inability is a governance characterized by dependence on political will, lack of continuity due the nonexistence of civil service, limited autonomy, insufficient budgets, absence of formal paths to fund themselves, shortage of technical know-how, and insufficient citizens' involvement. Thus, while a criticism to management of urban green spaces in developed cities is its focus on recreational services — with no attention to other ecosystem services-, management in Latin America is heavily constrained by funds that barely afford maintenance of basic infrastructure - with exceptions that we highlight in the manuscript. Consequently, managers of urban green spaces across Latin America have not successfully implemented adaptation measures that, for instance, European counterparts have - e.g. traffic management, information campaigns. In addition, these governance capabilities pose the risk of maladaptation. For instance, many managers in Latin America have formally resorted to a full closure of their premises during the COVID-19 lockdown but they have not successfully enforced such a closure, which likely has brought undesirable effects - e.g. more overcrowding than under a controlled no-closure scenario. We provide public policy recommendations, and a list of research questions specific to Latin America - an understudied region when it comes to both governance of urban green spaces, and the role of urban green spaces during the COVID-19 pandemic.
\end{abstract}

Keywords: Urban green spaces; COVID-19; maladaptation; governance; Latin America. 


\section{Introduction}

With over 90\% of COVID-19 cases occurring in urban contexts (United Nations, 2020), restrictions to mobility worldwide have made more evident than ever that urban green spaces support residents' physical and mental health, spiritual wellness, and social cohesion. For instance, focusing on 48 countries located across the world, Geng et al. (2020) have documented that from February $16^{\text {th }}$ to May $25^{\text {th }}$ urban park visitation was higher in comparison to a similar period in 2019. Visitors of green spaces in 2020 include people that would have not visited a green space in a regular year. In Europe, managers of Natural Protected Areas near urban settlements have observed new profiles of visitors - e.g. inexperienced hikers (McGinlay et al., 2020). Through 2020, urban green spaces have provided services even if no visits occurred - e.g. having a room with a green view in Tokyo, Japan, has been associated with lower levels of depression, anxiety and loneliness during the COVID-19 lockdown (Soga et al. 2020).

Together with the ever changing restrictions to mobility, visitors have brought with them a number of challenges to managers of green spaces. For instance, managers of National and Nature Parks in Europe have reported overcrowding, conflicts among visitors (regulars/experienced versus new/inexperienced), and conflicts among visitors and locals - unawareness of regulations and social norms applicable within these parks among inexperienced hikers is mentioned as one of the main reasons of conflict. Managers of European parks have responded to these challenges with measures that include temporary closure of specific sites, online updated on parking capacity and overcrowding incidents, replaced guided tours and school visits with online educational programs, among others (McGinlay et al., 2020).

Indeed, the designing and successful implementation of solutions to these challenges depend on the existence of an adaptive environmental governance. Environmental governance refers to the "set of regulatory processes, mechanisms, and organizations through which political actors influence environmental actions and outcomes" (Lemos \& Agrawal, 2006, p. 298). An adaptive governance sets the conditions to flexibly apply rules, learn through complex processes, and innovate during challenging times (Folke et al. 2005). In particular, an adaptive environmental governance enables a manager of urban green spaces to take the most advantage of available resources -including green space itself. Consequently, by providing mechanisms to guarantee provision of services from urban green spaces to residents, an adaptive environmental governance plays a key role in a city's resilience.

To the best of our knowledge, no previous study has documented how managers of urban green spaces in Latin America have attempted to accommodate the restrictions to mobility issued by their governments, and whether their governance arrangements have enabled them or have limited them. Filling this gap is relevant and urgent because COVID-19 is potentially more lethal in Latin America than in other regions.

This paper documents challenges faced by managers of urban green spaces across Latin American when designing, communicating, enforcing, and adapting COVID-19 mobility protocols within their realm of responsibility. We have carried out semi-structured interviews to 18 stakeholders -including managers, staff personnel, and a landscape architect - of urban green spaces in 14 cities of six Latin American countries - Argentina, Colombia, Ecuador, Guatemala, Peru, and Mexico. Through these interviews, we have gained insights into the governance of urban green spaces across Latin America.

\section{Related literature}

This section places the contribution of this paper within two literatures. One literature encompasses a rapidly growing number of studies documenting the role played by urban green spaces during the 
COVID-19 pandemic. This literature has overlooked the managers' perspective — with exception of McGinlay et al. (2020); Ordóñez et al. (2019) - and Latin America — with exception of Barona et al. (2020) and Konijnendijk van Den Bosch et al. (2018) on urban forests. The second literature of interest refers to studies documenting governance of urban green spaces. A recent literature review has concluded that urban green spaces have been studied mostly from a demand-side perspective which implies that factors determining provision, including governance, have been overlooked (Boulton et al., 2018). Also, Latin America and the perspective from managers of urban green spaces have been missed by the literature studying provision of green spaces (Boulton et al., 2018; Rigolon et al., 2018).

\subsection{Governance of urban green spaces}

Governance is "a social function centered on efforts to steer or guide societies toward collectively beneficial outcomes and away from outcomes that are collectively harmful" (Young, 2009). Current times' societies place a high priority to collectively reaching beneficial environmental outcomes. In this respect, environmental governance entails "the set of regulatory processes, mechanisms and organizations through which political actors influence environmental actions and outcomes" (Lemos \& Agrawal, 2006). Under these definitions, and loosely following Boulton et al. (2018) with regards to what we mean when using the term urban green space, we will refer to governance of urban green spaces as the regulatory processes, mechanisms and organizations focused on parks vegetated, and areas located in public lands, with emphases in public parks and gardens. Young (2009)'s normative definition is implicit throughout the paper — as one of the key discussions is what decisions, steer society toward beneficial outcomes when facing the trade-offs imposed by COVID-19.

The literature on governance of urban green spaces is sparse - in particular, in what respects to provision (Boulton et al. 2018). This literature has mostly focused on the emerging role of nonstate/non-governmental actors in the design, management and use of green spaces under strategies of participatory planning, communities participation, co-production, polycentric institutional approaches and other forms of strong stakeholder involvement (Boulton et al., 2018; Pincetl \& Gearin, 2005; Colding et al., 2013; Zingraff-Hamed et al., 2020; Lovell \& Taylor, 2013; Ambrose-Oji et al., 2017). For instance, Ambrose-Oji et al. (2017) discuss how the traditional centrality of local authorities in planning and managing urban green areas has shifted in Europe - where a number of social organizations, citizens and entrepreneurs have an active role ("with or without the active involvement of government") in managing urban green spaces, producing many instances of co-management, co-governance or co-production.

There are no many studies documenting the governance of urban green spaces in Latin America (Boulton et al., 2018; Ojeda-Revah et al., 2020, 2017). This condition may be partly explained by centrality of governmental organizations in Latin America -which implies their direct involvement in management, planning, funding and infrastructure building, leaving small space for involvement and coordination with other stakeholders. Among the few documented cases in Latin America, Konijnendijk van Den Bosch et al. (2018) describes how the lack of governance in Cochabamba, Bolivia, contributed to transform this City of the Eternal Spring into a chaotic urban complex with severe socio-environmental problems. In response to a lack of clear regulations to protect existing urban green spaces and promote the creation of new ones, local citizens got directly involved in the preparation of a urban forest master plan in 2016. Community involvement was encouraged through a process of active tree citizenship. A grassroots collective (No a la tala de arboles) was created to defend the city's trees. Gaining popularity in social media, it reached nationwide popularity which the organizers took advantage of to make introduce essential demands into the Municipal Tree Law adopted in October 2017. 
To understand the provision of governance, it is key to research on the management perspective - about which "we know surprisingly little" (Boulton et al., 2018). We know even less about how organizational arrangements and implicit political restrictions determine managers' motivations and resources to cope with demand of urban green spaces. In terms of the multi-level governance framework of Kabisch (2015), we have plenty to learn about how the four components for effective governance - operational, tactical (agenda development), networking, strategical, and reflexive (deliberation that allows adjustment of strategies and agendas) - are carried out in Latin America green spaces.

Attending the gaps in this literature, this paper focuses on the supply aspect of the governance of urban green spaces in Latin America by documenting the managers' perspective and challenges through COVID-19.

\subsection{Urban green spaces amid COVID-19}

There are concerns worldwide that the COVID-19 lockdown has triggered negative effects on physical and mental health of residents of all age cohorts, with consequences on cognitive abilities, stress and depression, school achievement, exercising, and overweight (Husky et al., 2020; López-Bueno et al. 2020; Wang et al., 2020; Xie et al., 2020b a). Additionally there is a documented increase in domestic violence that may be a result of confinement (Froimson et al., 2020; Piquero et al., 2020; SilverioMurillo et al., 2020).

Supported by longstanding literatures documenting the many services provided by urban green spaces, a number of studies have put forward urban green spaces as a source of resilience amid the COVID-19 pandemic (e.g. Samuelsson et al., 2020). For instance, Hanzl (2020) and Kleinschroth \& Kowarik (2020) have pointed out that cities must develop policies that guarantee provision of more and better green spaces - this recommendation applies to cities across the world, including relatively green ones in developed economies.

Focusing on Latin America, Cortinez-O'Ryan et al. (2020) have warned about the potential increase in health inequalities due to the severe restrictions to mobility and park use during the COVID-19 pandemic. They highlight that effects from measures such as closure of urban parks are impacting poorer residents more negatively than wealthy ones. Pre-COVID-19 intra-urban health inequalities would deepen because residents of affluent neighborhoods have more space at home to maintain physical activity, and more access to open green space - to mention a couple of factors directly related to the topic of this paper. They warn that measures that work in other contexts may not be enough in Latin America. For instance, regulating access to urban parks during COVID-19 lockdown may not by itself provide egalitarian access to outdoor recreation because a large proportion of urban, poorer residents do not live close enough to green spaces. The potential for a deeper inequality does not end there - due to typical criminal activity in urban parks located in poorer neighborhoods, it is possible that poorer residents avoid visiting these green spaces more than usual.

Research about Asian cities includes studies by Uchiyama \& Kohsaka (2020), Xie et al. (2020a), and Zhu \& Xu (2020). Uchiyama \& Kohsaka (2020) document that wealthier residents of Nagoya City, Japan, are less likely to increase their visits to green spaces during the COVID-19 lockdown - which in Japan was first implemented from April $16^{\text {th }}$ to May $22^{\text {nd }}$. This result is in line with what Cortinez-O'Ryan et al. (2020) has pointed out — wealthier residents can better afford stricter restrictions to mobility. Xie et al. (2020a) document that residents of Chengdu, China, self-reported poorer health status by the beginning of April, 2020, and the authors highlight the potential benefits from visiting urban parks available in the city of Chengdu. Via analysis of social platform data collected during the COVID-19 lockdown, Zhu \& Xu (2020) has documented that visitors to Beijing Park report more positive emotions inside the park, and that landscapes and plants are the main 
elements of people's expressions of positive emotions.

Research about European cases includes studies by Shoari et al. (2020), Venter et al. (2020), and Ugolini et al. (2020). For the case of England and Wales, Shoari et al. (2020) have quantified access to public parks and gardens in urban areas to inform policies aiming to decrease crowdedness during the COVID-19 lockdown. Venter et al. (2020) document recreational use of urban green spaces during the partial lockdown implemented in Oslo, Norway, from March $12^{\text {th }}$ to $31^{\text {st }}$, 2020. Using mobile tracking data from thousands of recreationists, they document that outdoor recreational activity increased by $291 \%$ during the lockdown period in comparison to a three-year average for the same days - both pedestrians and cyclists increased activity on trails with higher green views and tree canopy cover. Ugolini et al. (2020) have documented the effects of social isolation on the drivers of usage and perception of urban green spaces during the COVID-19 pandemic. They have conducted online surveys in Croatia, Israel, Italy, Lithuania, Slovenia, and Spain from March to May, 2020 -i.e. during the period in which restrictive measures were imposed in these countries due to the first wave of COVID-19. They authors highlight behavioral adaptions that include visiting urban green areas that respondent would usually have not visited frequently - e.g. walking to small urban gardens (in Italy) or tree-lined streets (in Spain and Israel)

One finding that has consistently been documented across case studies is an increase in visits from urban residents to green areas that are not urban (or peri-urban) but are near to urban settlements — these areas have presented themselves as safer options to access green spaces during the COVID-19 pandemic. This finding holds for a wide range of restrictions to mobility. For instance, McGinlay et al. (2020) have documented an increase in visits and visitors to 14 National and Natural Parks located across Europe - Estonia, Germany, Italy, Poland, Slovenia, Spain, Sweden, and UK. Also, Ugolini et al. (2020) documents that residents in Lithuania have increased their trips by car to green areas located outside cities. In Honk Kong, Ma et al. (2020) report a surge in the number of visitors to 12 country parks.

\section{Materials}

We collected qualitative data from interviews with managers of urban green spaces in six Latin American countries. Their narrative was complemented with quantitative data reflecting the degree of stringency at national levels and with mobility data reported by Google.

\subsection{Semi-structured interviews}

We have gained insights into the governance of urban green spaces across Latin American cities amid COVID-19 by implementing semi-structured interviews to 18 managers or staff members of municipality agencies in charge of green spaces in Salta (Argentina); Bogotá (Colombia); Quito and Cuenca (Ecuador); Guatemala and Villanueva (Guatemala); Aguascalientes, Guadalajara, León, Mexico City and Monterrey (Mexico); and a real-state architect with knowledge of green space management in Piura (Peru).

A semi-structured questionnaire was implemented via a Zoom meeting to a focus group of park managers from Quito, Ecuador and managers of two parks in Monterrey and Mexico City, Mexico, and a top-level personnel from a system of metropolitan parks in Guadalajara, Jalisco (Mexico). The rest of the interviews were carried out with an adjusted questionnaire, one-on-one, via Zoom meetings — with two exceptions: the interview with the manager and staff member of the largest urban park in Aguascalientes was carried out in situ, and the members of Bogota's Instituto Distrital de Recreación y Deporte (IDRD) preferred to send written responses to our questionnaire. 
Literature on Latin American urban green spaces is sparse, so we have looked for a wide perspective that allows us to formulate a general view of how different characteristics may have played out in their intent to manage COVID-19. We hev looked for a diverse selection of countries that allowed us to picture the overall situation in Latin American urban green spaces:

- Diversity of Latin American countries

- Variation in the type of governance arrangement, including the most common type (a municipality agency in charge of dozens of parks and green spaces maintenance, embedded either in a public services agency or a natural resources area) to metropolitan parks.

- Diversity in the cize of the cities. We cover experiences in country capitals (Bogotá, Mexico City, Quito); middle-size cities (between one million and two million people) such as León and Aguascalientes, in Mexico; and small-size cities such as Salta, Argentina, and Cuenca, Ecuador.

To recruit interviewees we resorted to personal networks with public officials of the central area of Mexico (states of Aguascalientes, Guanajuato, Jalisco, and Zacatecas) that helped us putting us in contact with park managers; direct contact through email in the case of non-for-profit organization that manages periurban natural parks in Guatemala; and finally we requested the support of the National Parks Association of Mexico (ANPR), which has a wide network with park managers throughout Mexico and other Latin American countries, mostly with parks managers that attend their annual parks congress, which to our knowledge is unique in its type in Latin America.

Comparing contacts from ANPR with other contacts we conclude that there is a bias that we should make explicit. Their attendants are directors or top managers of metropolitan parks or municipality agencies that have in common a concern for improving their management skills, that have a budget for learning about other experiences and disseminating their cases, and likely more motivated about their endeavours that other managers. While we did not did lack of motivation in managers that do not belong to an association or that do not participate in events outside their city to show their results or challenges, they have not developed a channel to know different strategies or experiences that may be useful for them. While we tried to balance our sample with other cases, which very likely are more similar to the general situation in park management in the subcontinent, we do not have a representative sample. However, we can affirm that using the subsample of managers that participate in congresses we have an upper-bound in terms of knowledge and resources, that allow us to affirm that conditions in other places are very likely much more precarious than those found here.

Table 1 enlists the post of the respondents, agency, the parks they are in charge, the level of government of the status of their organization, and the day of the interview.

To implement the methodology, we respond first to four key questions related to how urban green spaces are managed and how they relate to urban resilience:

- What protocols and actions did they followed to manage during and after the instruction of lockdown? Did the citizens comply with the rules?

- What are the strategic goals of their park or system of parks?

- What are the characteristics of their infrastructure and their human capital, and how it allows them to accomplish their objectives?

- What is the governance arrangement of their park or system of parks? 
It is important to highlight that none of the questions listed above were asked directly to the respondent with the phrasing presented here. Through a conversation, the respondents provided a narrative on what they do and how they do it, on their organic structure and budget, on their perceptions about parks and the pandemic, and on the plans they have and what they think about the future. Their narratives allow to trace categories of activities that constitute the chore of their type of governance. Finally, we derive suggestive evidence on which governance arrangements seem to produce resilient results.

Interviews lasted on average 50 minutes each. Seven interviewees were contacted with the help of the director of Asociación Nacional de Parques y Recreación (ANPR), Luis Romahn. The interviews were realized between September 10th and October 30th. The interviewees were told about the purpose of the project and accepted to be recorded for transcript purposes only. They agreed to be mentioned as interviewees in documents and reports. Some of the interviewees sent the presentations with the protocols they implemented to attend the population during the pandemic. One of them shared shapefiles of the park polygons to show the geographic distribution of the system.

The interviews were analyzed to trace specific urban park governance features and determine in which cases they revealed adaptive governance features (flexibility, learning, innovation), under the premise that such features were linked to policies that contributed to control spread of the virus and at the same time keep providing urban green spaces for physical and mental health. Overall, following general process tracing principles (Beach \& Pedersen, 2019; Bennett \& Checkel, 2015; Kay \& Baker, 2015), we use the interviews to build a meaningful chain of events, from the specific activities performed at parks to the results in terms of resilient policies, guided by hypotheses that connect adaptive governance with policy results.

\subsection{Data on restrictions and actual mobility}

From our interviews, we captured the specific measures established at the urban green spaces managed by our respondents. Given that those result from general guidelines defined by national governments, to identify the degree of restriction applied in each country we used the Oxford Stringency Index Thomas et al. (2020), which summarizes nine types of measures - school closing, workplace closing, cancellation of public events, restrictions on gatherings, closing of public transportation premises and services, stay-at-home requirement, restrictions to within-country mobility, international travel controls, and public information campaigns. For further details, see Thomas et al. (2020).

To estimate overall visitation to parks during our period of study, we used Google Mobility Reports (Google LLC), which estimates the percentage change of visitation to parks as compared to a baseline, determine as the median visitation for the corresponding day of the period from January 6 to February 6, 2020. Under the category Parks, Google estimates visitation to 'local parks, national parks, public beaches, marinas, dog parks, plazas, and public gardens' (Google LLC). Data collection is based on the location history data from user's mobile devices, cell phones in most cases. There should be bias in poor areas, due to the comparatively lower percentage of people with cell phones and the quality of the telephone carrier antennas. While these areas should entail underestimation of the mobility, given that the data shows the change regarding a baseline with the same biases

and that the data is aggregated at the municipality/district/cantón level, which include all levels of socioeconomic groups, the bias is not of concern for our purposes. 


\section{Governance of urban green spaces in Latin American cities}

Applying Lemos \& Agrawal (2006)'s definition of environmental governance to our subject of study, we aim to identify the processes, mechanisms and organizations that interact to design, build, maintain, and enhance urban green spaces in cities across Latin America.

Decisions arising from a governance arrangement include those that can be thought as generic - e.g. defining a schedule for visitors to access a green space - and also those more complex, specific decisions that may or may not be easily changed once they have been taken - e.g. share of green area versus paved spaces within a urban park, or tree species that will be planted. Depending on the governance system in place, some or many of these decisions may be carries out by the same agency in charge of the maintenance and operation of the area or in coordination with neighbors, other governmental agencies and/or non-governmental stakeholders - e.g. topics covered by workshops organized at the premises.

The specific governance arrangement under which those decisions are taken facilitates or deters the necessary adaption when a society is facing a crisis such as the COVID-19 pandemic. The rest of this section describes the governance models of urban green spaces that have been identified based on our semi-structured interviews to managers of urban green spaces in cities across Latin America. Without being exhaustive, these models cover a wide range of the governance arrangements followed in Latin America, according to our interviewees.

\subsection{Governance types}

For the case of natural parks, Eagles (2008) states that the key features of governance emerge from the combination of three characteristics: who is the owner of the land, their source of income, and the identity of the management body. In the case of urban parks and other green spaces, land is of public ownership in most cases, and as a general rule with exceptions their funding is also public (from the budget of some level of government). Therefore, we single out the management bodies in charge of the green spaces as the key variable for categorization. In general, who is the management body is also strongly related to the characteristics of the park (size, amenities, and diversity of activities). Table 2 shows which cases correspond to each governance type.

It is noteworthy to point out that in all the governance types we identify, the urban green space we refer to is a park (neighborhood, urban, or natural park) with the exception of municipal types of governance, which includes a variety of green space, that form part of a city's green infrastructure. While is not a single definition of park, the most used definitions approach the term based on size and the type of service supplied to citizens, and use the terms urban park and neighborhood park. Reviewing planning documents of Mexican cities (municipal governments) Ojeda-Revah et al. (2020), finds that many of the most populated cities in Mexico use a manual by Secretaría de Desarrollo Social (1999), which defines neighborhood parks and urban parks: the former are defined as wooded areas for public access, with rest areas, playgrounds, and other equipment, between three and twelve acres, are located within neighborhoods, and are planned for cities of at least 10 thousand inhabitants; the latter is a open area with equipment adequate to different section, that typically include recreation, sport, and education facilities, and have an extension between 9 and 78 hectares. These parks are planned for cities of at least 50 thousand inhabitants.

A current project of an Mexican Official Norm (a rule of mandatory character, issued by agencies from the Executive at federal government, after technical discussions to set definitions standards of different types) to define public spaces by Secretary of Agrarian, Territory and Urban Development, uses a much simpler definition: "spaces within a human settlement, used for meadows, gardens and trees, that allow and contribute to rain infiltration and that have been explicitly defined for walk- 
ing, resting and social gatherings." Newer definitions underscore the regulatory ecosystem services function of parks, not only their cultural services.

In Cuenca, Ecuador, the public entreprise use categories based on the scale to which the park is used: neighborhood parks are used by the neighbors of the park; zonal parks serve many neighborhoods and urban parks serve people from all the city.

\subsubsection{The municipality agency type}

We use the label municipality agency type to describe an arrangement under which a municipality entity (a secretariat/ministry) is in charge of managing public urban green spaces. The Public Services subtype is the most frequent approach, where an area within a Public Services or Office is in charge of maintaining and operating parks and other urban green spaces, such as medians, gardens, roundabouts and others. A more recent approach in big cities is that another area (likely an Environmental Resources Secretariat is the frequent approach), is in charge of the strategic decisionmaking related to urban green spaces, such as landscaping based on a vegetation palette or defining which activities to carry out, but a different municipality area is in charge of maintenance and some operation decisions. We label this subtype as the Inter-agency approach, to convey the arrangement of a set of municipal entities carrying out different tasks related to urban green spaces management.

Importantly, the Public Services label does not only refers to the level of government. A first distinctive feature of this governance model is that provision of green spaces is only one of several tasks carried out by the public office. Conventionally, a municipal Public Services office is in charge of public lighting, waste collection, and management of public spaces — of which, green spaces is only one category. In most cases, the Public Services Office will have a dedicated area for management and maintenance of urban green spaces and parks.

While there is a very wide variance in the municipalities' population, budget, staff, training, political salience and many other features, and that mirrors a noteworthy difference of Public Service agencies, more frequently than not, provision of urban green spaces falls behind when prioritizing resources among these services. Thus, traditionally underfunded municipal Public Services offices allocate just enough resources to afford maintenance that keeps green spaces running. Case in point, municipal green spaces frequently have no public restrooms - and, if restrooms are installed, their maintenance is far from adequate (Quintanilla \& Ayala, 2018).1

There are exceptions to the underfunded/under-staffed Public Services subtype. In the cantón (an administrative unit similar to the municipality) of Cuenca, Ecuador (the third biggest city the country, after its capital Quito and Guayaquil) parks and gardens are in charge of the Public Company of Sanitation (EMAC, in Spanish). EMAC is a public company with its own assets, has legal, administrative and management autonomy. The head of EMAC is appointed by a directorate. Being a public company, they have a clear set of performance indicators and a focus on efficiency, which might be different from more traditional public services arrangements, but they are similar to its counterparts in the continent in the relevance of maintenance as the key function of the agency: "We think Cuenca may have one the best maintenance services in Latin America. We are very efficient". Their funding sources are also different from most municipal cases: by formula they are allocated a budget from electric and telephone lines fees.

Under the Inter-agency subtype, the allocation of different responsibilities to a set of municipality agencies from different Secretariats or Areas, stems from the need to highlight policy objectives

1 Quintanilla \& Ayala (2018) made an inventory of basic infrastructure in 87 parks distributed in 14 (out of 31) states in Mexico plus Mexico City, and found that $51.72 \%$ have restrooms, without indicating if they function or not. Given that they used a convenience sample that included well-known parks, all in large cities located in comparatively well funded municipalities, the numbers are likely much lower in a representative sample including smaller municipalities. 
other than maintenance. In the case of the city of León, in the Mexican state of Guanajuato, a Natural Resource Area is the main manager of parks, as a statement of the relevance of an ecosystem services perspective, which has impacted the type of projects carried out by the municipality (such a tree-inventory and a rethinking of the objectives of the maintenance of green areas beyond aesthetic functions).

The emergence of demand of new services and different perspectives on what a park should provide has modified the conventional approach of public services agencies. For instance, environmental activists and national climate change policies have motivated local governments to think in how the manage their greenery from an ecologist and mitigation perspective. In the city of León, Mexico, the Secretary of Natural Resources is in charge of the parks, and Public Works services provides maintenance and minor infrastructure projects. Under this perspective, the municipality is trying to create a system of parks to integrate the urban green of the city, which includes the municipality's parks, metropolitan parks and a few managed by different municipal agencies. This organizational change impacts moves the focus from aesthetics and maintenance to an ecological oriented management.

Overall, according to our informants, in Argentina, Ecuador, Guatemala, Mexico, and Peru, many urban green parks, most neighborhood parks, and other public urban green spaces are managed by the municipality under the Public Services model.

To put in context the relevance of documenting the municipality governance model of urban green spaces, we highlight that there are 29,520 parks managed by municipalities — without counting gardens and other smaller urban green spaces - only in Mexico (INEGI, 2019a). In spite of the astounding number of parks, gardens and other green areas managed by municipalities, and that they are likely the closest green areas to individuals, their role has been overlooked, perhaps because the academic literature has focused on topics such as ecosystem services, stakeholder new forms of participation, or resilience, which are more salient and less fragmented in the case of larger urban parks and periurban forests.

\subsubsection{Dedicated park management type}

In contrast to the municipality model, where an entity is in charge of many neighborhood parks and some urban parks, the dedicated park management refers to the existence of an administration entity (at least a manager, an operative and administrative staff) in charge of a single park. Usually, these are urban parks above of at least ten hectares that attract visitors from all the city areas.2 These parks may be managed by a state or municipal government, but not through an office with a portfolio of responsibilities including green areas, but under a separate office or a decentralized entity that reports to a Secretariat but has its own bureaucratic structure. In most cases these parks have access to better trained and diverse human capital (they may include landscape oor ecological restoration specialists) and better budgets.

Dedicated management parks usually have a variety of gardens, a lake, running tracks, zoo or wildlife areas, a variety of sport courts, and an offering of activities, from educational to races, competitions, concerts and others. Parks in the dozen of hectares may have museums, auditoriums, vivarium, orchards, a variety of gardens, and ecological reserves.

More an exception than a rule, sometimes neighbor association may manage a urban park. Our cases include La Mexicana, a 28 hectares park in the middle of a very affluent business district in west-side of Mexico City. This park does not receive funding from the government and depends on

\footnotetext{
${ }^{2}$ Mexico's Parque Tamayo in the state of Nuevo León with 14.7 has is considered small from the perspective of an urban or metropolitan park; La Mexicana has 28 hectares. As a reference, a country's flagship urban park may reach hundreds of hectares: Chapultepec in Mexico City has little less than 700 hectares; Central Park in New York has 340 hectares; Parque San Martín in Mendoza, Argentina, has 324 hectares.
} 
the permits sold to restaurants located within the park, services to business or rent of spaces for movie or TV sessions.

Other types of urban green spaces are ecological corridors for use of public enterprises, such as the area around a hydroelectric in Quito, Ecuador. The objective of this area is to protect the biodiversity of the area, to serve as recreation of the employees of the state-owned company, and work as a buffer of the hydroelectric which is very close to the city of Quito.

\subsubsection{Polycentric management}

In contrast to the municipality model, a polycentric management type entail the participation of agencies from more than one level of government, typically state and municipal government agreeing on how to manage a network of parks.

In contrast to the dedicated management type, which refers to the management of a single park, a polycentric model entails the management of a network of parks.

A relevant case is the one by the Agencia Metropolitana de Bosques de Guadalajara (the second largest city in Mexico, with more than 4 million people, counting the population of nine municipalities that integrate the metropolitan area), which was created by the state government and manages ten metropolitan parks of the Metropolitan area of Guadalajara, integrated by nine municipalities. Managing a system of parks, they are able to coordinate their staff to implement monitoring services. The Agencia operates in coordination with the municipalities through the Institute of Metropolitan Planning (IMEPLAN).

\subsubsection{Not-for-profit management}

As in the case of the dedicated management type, the not-for.profit management has also a manager, an operative crew and may have an administrative staff, but it is managed by a not-for-profit NGO, under an agreement with the goverment of a municipality to protect a natural area and with the permission to develop a business plan to financially sustain their activities.

In Guatemala, there are parks located at centric city's ravines managed by a non-for-profit organization under an agreement with the municipality. Usufruct is the common legal figure for those agreement. The municipality allows an organization to implement an approved business and management plan in an ecological area. The commitment is that the non-for-profit conserves the area and gets its own funding, from international donors, entry fees to the park and sale of services (food, banquets, training). It is the case of Parque Ciudad Nueva, Guatemala, one of the twelve parks managed by the non-for-profit Fundación Calmecac. The funding comes from the fee that charge for entrance to the park, the sale of services (workshops, banquets, guided hiking) and products (plants and seeds).

They have received also funding from international donors, such as PNUD and GEF. They work with communities, organized groups, municipalities, private sector, indigenous groups. As an environmental not-for-profit, they have an ecosystem services perspective: "We are a Foundation that values life and biodiversity (...) One of our goals is to conserve the trees of the city, because they catch rain water and infiltrate to the aquifer. The ravines are the lungs of the city, we have the mandate of conserving those areas. The area is classified as Municipal Biological Corridor." 


\section{Challenges faced by managers of urban green spaces across Latin America during COVID-19 times}

At the beginning of the pandemic, public spaces managers shared a single objective - collaborating with national and local governments in implementing a set of social distance measures to reduce the spread of the SARS-CoV-2. The recommended stringency of restrictions to mobility depends on where in the COVID-19 infections' curve a country is located (World Health Organization, 2020). Figure 1 shows the evolution of the stringency of measures issued in the six countries under consideration in this study, from January 1 to October 30, 2020.

As illustrated by figure 1, stringency in all six countries was similar at the beginning of the pandemic. The six countries issued mobility restrictions at the national level during the second and third week of March. Between the second and third week of March, Argentina, Colombia, Ecuador, Guatemala, Mexico, and Peru implemented lockdown directives that included the closings of all activities labeled as non-essential, including parks.

The Stringency Index is constructed based on the formal measures enacted by each country. The implementation of the measures is a different story, as the specific mechanisms to achieve compliance and the effort to enforce them varied widely in terms of strictness. Some countries implemented curfews and applied penalties or even days in jail for non-compliance ${ }^{3}$ Other countries tried to implement restrictions using softer measures such as requests to the population to 'stay at home' without any penalties or enforcement by authorities, as in the case of Mexico (aside from that, Mexico closed non-essential businesses as other countries). These actions were into place from the second week of to the third week of March, with few days of difference between countries 1. Mexico for instance was the last to implement strict mobility restrictions among our study cases, on March 23rd.

The differences in enforcement produced different levels of actual mobility, as captured by Google Mobility data. In figure 2 we show the actual mobility in parks as captured by Google LLC for one state for each of our countries of study. Mobility in parks in Lima, for instance, has a very distinct pattern, where mobility drops close to $90 \%$ during weekends of April and May, where there was an observed curfew (see figure 4). The pattern in Mexican cities in much noisier, suggesting a much less coordinated social response, probably associated to the laxity of the enforcement and that the communication message at the national level was inconsistent and did not convey the urgency of the pandemic to the population (see figure 3. In July and thereafter, mobility in the city of Aguascalientes was just $20 \%$ below the baseline during non-pandemic times. Mexico City shows a more restricted mobility, due perhaps to being the urban area with the highest level of contagion and deaths, and also where the local government presented a more consistent message regarding the need of restricting movement.

The rest of this section describes how managers of urban green spaces across Latin America have faced the challenges of designing, implementing, enforcing, and adapting restrictions to mobility within their realm of responsibility. Also, this section elaborates on how governance has supported (or deterred) managers' success in pursuing these challenges.

\footnotetext{
${ }^{3}$ Newspaper El Comercio, from Ecuador, reported by the end of August that 130,670 persons had been sanctioned for violating curfews or other restrictions related to the pandemic response. In most cases they were charged with penalties between 100 and 400 USD (a considerable penalty, considering the yearly GNI percapita in Ecuador is 6,090 USD), but 1,979 of them faced criminal processes, and some were already in jail.
} 


\subsection{Designing and communicating mobility protocols}

The COVID-19 pandemic has faced managers of urban green spaces worldwide to the challenge of designing protocols to restrict mobility of visitors to the spaces under their responsibility.

Design and implementation of temporary restrictions to mobility is not a foreign task to managers of urban green spaces - e.g. during the Mexico City Marathon, managers of Bosque de Chapultepec restrict mobility within and in the surroundings of the park; at a different scale, races, concerts, festivals and other public events requiring specific people distribution across the facilities, are organized through out the spaces across a regular year by these managers.

However, four additional layers have complicated the design of protocols in COVID-19 times in Latin American cities.

The first layers refers to develop impromptu protocols to use the park under the loose guidelines from national governments. Regular activities such as races or concerts are arranged in coordination with cities' agencies, social organizations and private entrepreneurs, with enough anticipation, a budget allocation and with a know-how on how to proceed.

The second layer refers to the difficulty in adapting personnel to perform tasks different from those they regularly perform. It is noteworthy that public services type managers had more rigid strategies to redistribute personnel from operation to regulating access for instance, but had the resource of using temporary job programs from the municipality or the national government to perform those duties.

The third one refers to the uncertainty on the duration of the measures. Managers are used to plan budgets and personnel tasks according to scheduled activities with defined time tables. Management is not designed nor prepared for uncertainty.

A fourth complication have arisen from the decrease in funding that the pandemic itself has provoked - most Latin American public administrations have under-funded and under-staffed public agencies in charge of urban green spaces. In the case of Villanueva, Guatemala, the estimated a budget cut of $50 \%$ for 2021 .

A fifth distinctive feature is that some managers have had to consider whether and how to implement restrictions not only within but also in the surroundings of the urban green spaces with the buffer around the urban green space being part of the parameters to be decided. This required coordination with municipal authorities, and was no exempt of problems such as complaints from car drivers that considered a nuisance the conversion of a lane to a park and traffic accidents.

Restricted by these layers of complexity, most park managers resorted to restrict the use of the parks and communicate the decision to the citizens.

Urban and metropolitan parks with an entrance closed the parks. Also, in Mexican cities some neighborhood parks have physical perimeters and they also were closed. In the other cities of our study, most neighborhood parks are open. The common measure in these cases was to communicate to the citizens that the parks were not accessible due to the pandemic using banners, newspaper and radio messages. The access was established for exercising with the recommendations of using the park during an hour only. Courts and playgrounds were closed.

In some cases, parks personnel or local police asked people to live, especially at the beginning when people were misinformed or skeptical about the need of the restrictions. A common measure was also to enclose some areas such as playground or main entry points with yellow ribbons, which were commonly vandalized during the nights. Most informants report that most people respected the lockdown after the first days of skepticism, but they reported some a few young people evaded the restriction during nights.

In places where the restrictions lasted a long period, there was a combination of tolerance and relaxation in the implementation of protocols. In Guatemala the curfew (with different time and 
days adjustments through outt the period) lasted six months. Around June, they decided to let the people exercise, but to dissuade those that crowded in specific areas. Only 'people in movement' was tolerated. In Cuenca, Ecuador, and Zacatecas, México, parks were closed until the period of the interview - in October - and there were no plans to reopen. In some cases, as in Zacatecas, informants argued there was not enough people to instrument a regulated access (measuring temperature, requesting masks or monitoring a one-hour only restrictions).

Beginning in June, many parks were opened in Mexico, following the protocols and under the conditions set by the Mexican Secretary of Health: they requested masks, provided antibacterial gel at the entrance, and established a person at the entrance to regulate access, measure temperature and in some cases make a register of users. This protocol is very similar to the rules implemented in Guatemala when they began pilot programs to allow access.

The set of measures were the same as those adopted in natural parks of Europe, according to McGinlay et al. (2020): one-way tracks, number of people allowed into facilities, or register of visitors to parks. Other measures reported by McGinlay et al. (2020), like cleaning constantly, was mentioned by few managers.Banning cash payments was not cancelled, and smart city appliances such as apps to report people on the number of visitors in specific location was not even possible given the equipment and training available. Regarding the spread of information as to how to use parks safely, there are not much differences, as in Latin America there was use of banners, newspapers, social media in the case of some metropolitan parks and in some instances such as Villanueva Guatemala, spread of information through neighbor networks.

\subsection{Non-compliance: 'the people did not follow the rules, so we had to close'}

In all cases, park managers followed national established rules, which in all cases set a strict closure by the end of March, with wide variation in its enforcement. For instance, Ecuador and Guatemala established a curfew, while Mexico closed 'non-essential businesses' but did not enforce people mobility restrictions.

In June and in some cases in August or September mobility restrictions at the national level where relaxed. Municipalities - and in some cases, park managers - were able to decide which services could open and under what conditions. In this phase non-compliance became a regularity that tested managers abilities and resources to warrant a safe access to parks.

Managers under inter-agency and dedicated management governance types tried to provide a controlled access to the parks, but found that wanting social response could derive in crowding and contagion, so they decided too follow more restrictive policies. The public services subtype as a general rule decided they were not able to provide a safe access and decided to close parks or restrict entrance.

Inter-agency and dedicated management types in Mexico in all cases found social resistance to minimal protocol requests, such as lack of mask use, crowding in restricted areas by children and young people, and joggers frequently did not follow the one-way rule. These managers showed concern that without compliance with the rules they will be forced again to close the parks. The experience in Guadalajara was common: "We are very surprised to see, with the monitoring we go through the parks, that adults in Guadalajara do not comply with the use of masks. Adults are the less respectful of this rule. Even if affluent areas in parks as Metropolitano or Los Colomos, people do not comply with the use of masks." In privately managed La Mexicana they found that "citizens have not understood the relevance of masks. Even when the park was open, some people preferred to keep running or walking in the contiguous street, even when the park is much more beautiful, 
because in the street nobody demands the use of a mask."

Park Tamayo opened again at the beginning of September. Given that a great number of people attended, they decided to close again to reduce the risk of contagion. At the parks of Agencia Metropolitana of Guadalajara, they used all the available resources to warn users the park was closed: yellow ribbon (which was vandalized the very next day), banners, social media, audios. At the beginning, some people were upset as they considered open space should remain available for their use. There was some degree of tolerance to allow users safe uses of the park (taking a walk using masks), but when Agencia noticed some areas were crowded, they decided to close the park completely.

Personnel to monitor compliance with protocols was even scarcer in parks under the municipal public service governance type. As a general rule opted to close the parks with physical perimeters, as in the case of Zacatecas. In Jesús María, Aguascalientes, they were able to use temporary employment programs from the municipality or state government to supply controlled access in a few parks.

Compliance was hard to implement in Villanueva, Guatemala too, even though the government implemented penalties for those not observing curfew: "The first months people were very committed to the emergency declared by the government. Later, they started to find ways to avoid the rules. Some started to go to the parks and bring their kids. We began to patrol the parks to ask people to leave. We used three strategies: public force, yellow ribbon and communication through neighborhood leaders, we talked to them explaining why it was for the safety of everybody that people did not use the parks. A violation of curfew could mean up to one month in jail. When there was not curfew, we used the patrols, ribbons and help of the community leaders."

After three months, people from Villanueva requested frequently, "when are you going to open?". Young people in red zones [locations where criminality rate is high] started to go to the parks and break the yellow ribbons. There was an increase in the cases of violence, and the municipality launched a communication campaign informing that girls were suffering abuse and violence. At the beginning of the pandemic, they had allowed people to take a walk in the parks but restricted some areas prone to agglomeration. But unfortunately, a few people broke into the restricted areas and they decided to close the parks that had physical barriers.

\subsection{Demand for access: 'When are you going to open the parks?'}

After the first months of strict confinement, park managers faced a tension between contributing to restrict mobility in order to control virus spreading and the benefits lost due to lack of access to parks, which included mental health issues, physical inactivity, and domestic violence consequences.

All managers of our study reported that after the first weeks of confinement, citizens requested through e-mails, phone calls and personnel petitions to them or the majors, that they opened the parks. Public services types decided to keep restrictions due to the limitations to implement a safe access, while inter-agency and dedicated management developed strategies to find out what rules could allow the to supply the service in a safe manner. While the decision to restrict access seems as the safer bet given the social response, the managers acknowledges that crowding only moved from spaces such as parks to sites that were less ventilated and with higher density.

In Villanueva, Guatemala, where in some neighbors visiting parks is the only recreation activity for some families, they highlighted stressful conditions due to the confinement, and mentioned they have heard first-hand of domestic violence problems affecting specially girls. People requested frequently, "when are you going to open?". Young people in red zones [locations where criminality rate is high] started to go to the parks and break the yellow ribbons.

After eight months of confinement, many small gyms went broke: "For many, the only gym available will be the tiny park with the exercising machines. It is a very important hub for mental 
health. When you interact, your internal demons appease."

In Quito, the curfew suspended valuable entrepreneurial activities for poor communities that work in downtown.

Parks managed by municipalities in Mexico, which were not able to provide service, also received many citizen demands and requests to use the service. In Zacatecas, the mayor received directly many petitions to open the parks in a program called Public Audience: 'Allow us to open the court.'

In Jesús María, Aguascalientes, where fenced have been closed, there have been citizens' demands to open them: "During the pandemic, the green areas have become more relevant. The last days we had calls from the citizens asking when we were going to open. (...) People that exercise are those that request the access. I think they need it even for emotional reasons. It happens a lot with older people, they go to the gardens as their only activity. (...) I think green areas have become more important that they were before the pandemic."

The manager of Cuenca, Ecuador, is aware of the role played by parks regarding physical and mental health: "Parks have had an important role during this pandemic, allowing people to go out of their homes. That they are able to breath after strict confinement at home. Picture people three months confined at home. If they do not go to the park, they don't have anywhere else to go. Problems such as depression arise. In extreme cases, there are even suicides. Also, there is domestic violence, when people is locked, in machista societies we have those kind of problems. It is very important that people have some place to go out of their homes."

\subsection{The challenge of an adaptive governance response: "We should find a way to go to the park and be safe"}

The trade-off between controlling the virus through mobility restrictions and supplying physical and mental health services allowing access to parks is a complex one. Resourceful park agencies may offer a higher level of services supply for a given restriction level, compared to agencies without staff and resources.

The efforts to develop innovative strategies to allow safe access was tried in dedicated management and inter-agency types. In the case of public services, smaller cities such as Jesús María and Zacatecas decided to keep facilities closed. Larger agencies in Cuenca, Ecuador and the municipality of Guatemala were able to pilot controlled access plans. Most innovative responses were found in dedicated management managed by a private association, in the case of La Mexicana in Mexico City.

Awareness of the self-limitations to supply safe access, led managers to close parks when they were able to do it. The risk is that closure is not enforced either and neither goal (control the spread of the virus and supply park benefits) is accomplished. In some cases, alternatives for safe access were actively sought after.

Parks under the municipality public services governance type take from granted from the beginning that a controlled access was not possible. In Zacatecas, the secretary of Public Services considers that it might be possible to open the parks if they had enough personnel to follow a protocol, but they do not have enough staff to keep the parks open. Therefore, parks were closed for six months (without a date for re-opening as to the date of the interview).

In Jesús María, a one hundred thousand municipality in conurbation with the one-million people capital city, Aguascalientes, they have closed the parks due to lack of personnel, but they would be interested in finding out a way to do otherwise: "The major is very interested in opening the parks, there is a concern for the people, after so much time without going to work. If they knew about experiences in some other places, they could use it to open more parks (...) We want the people to feel safe and use the spaces to get out the stress we are living." 
Conditional of not being able to provide a safe access to citizens, the decision to close the parks could be considered the right response. It avoids maladaptation, understood as providing as trying to provide a service without the personnel and resources to do it safely. As stated by a municipaly park manager, "[they maintain parks closed because] we do not want to add causes for massive contagion." However, it is uncertain whether closure has been an effective policy to control contagion: "We closed the courts and parks but there is a contradiction. We have tianguis (street markets), and they are overflown with people, where brigades of sanitation are there with gel and telling people to wear masks."

Under the inter-agency governance model, an adaptation approach was tried. In León, in June they implemented the typical protocol and created a register to track contagions. They allowed entrance and if someone did not comply with the rules were banned to enter again. In some areas, they looked for using open spaces contiguous to parks for physical exercising.

Under the inter-agency governance system, flexible and innovative measures were implemented. The state government of Jalisco restricted the visitation to 25\%. For each of their parks, Agencia implemented a flag system with red, yellow and green indicators. When they reach yellow, it is an indication of starting to tell people using a megaphone to prepare their exit of the park or go to a park with less people. They are able to do this having a network of parks and centralizing the information on the current level of visitors. The communication is relatively simple, with people monitoring parks and reporting the corresponding flag of each park to a person in charge of the coordination. The staff is not abundant, 21 persons in charge of quality and control monitors 12 parks, but they coordinate to make an efficient revision.

In Cuenca, Ecuador, the public company in charge of parks in Ecuador has been able to hire based on technical criteria. The person in charge has followed closely the COVID19 progress in Europe. Anticipating what was going to develop, seeing the case of Spain and Italy, he developed a protocol, ready when the government ordered the closing of all non-essential activities. The first months they closed the parks. After that, they limited visitation to $30 \%$ of the total capacity. Vulnerable groups, such as elderly and children, cannot enter the park. They allow exercising, walking, biking. The playgrounds and courts are closed. The commerce that was allowed into the parks is forbidden. They don't have enough personnel to monitor the protocol is observed everywhere (Cuenca's parks are not fenced): "The protocol is not only about controlling behavior, it is also about information. We trust the people receive the information through social media, that they know what they can do and what they should bring. Prohibition only it is not the solution. That is what we have seen during this pandemic, that happens all over the world. If people is not conscious, you cannot have any type of control."

In the municipality of Guatemala, they decided to close the parks that had a physical barrier and inform through the auxiliary majors (there are 21 subdivisions in the city, each with an auxiliary major) that any other park should not be accessed. The people understood well the decision. Between March 17th and October 4th, parks with a gate were under lock, and there was the instruction not to visit the other parks. The national and municipal police had the order to instruct the people to not visit the parks. At the beginning of October, they started the pilot to begin to open the spaces. "It is possible to open the parks, but we cannot monitor if the precautions are followed in the 400 parks. That is why we divulge the information between neighbors. We began with only four parks to verify things go well. Holding hands together we take some steps to make progress."

After the first month, people started to use open spaces, taking advantage of the program Steps and pedals, consisting in transforming a key artery of the city into a pedestrian area during Sundays. That day they opened a selection of parks. During the pilot, they opened park Minerva, close to the Steps and pedals area. In this park they had 1500 people in that day, when the regular occupation for a nine hour window was around 2000 people. A park outside of the area had less than 200 people. 
On July 16th the manager of La Mexicana took an uncommon decision, in coordination with the major of Cuajimalpa - they decided to 'open' a 2.5k area of the contiguous avenue to the park as an area of the park, for walking and jogging. They used two lanes of the avenue for three weeks. Converting roads to pedestrian street for a day is a practice in big avenues (such as centric Reforma in Mexico City, or common in Colombia) during Sundays, but uncommon for weekdays.

On August 3rd, La Mexicana opened the park with a restriction of $60 \%$ of the visitation. To coordinate social distancing, they painted 2.5 meters of diameter white circles with acrylic paint in the gardens, with a distance of 1.5 meters between circumferences. "The space is enough for a small family or a couple with a dog, and it creates a feeling of closeness to the people while keeping safe distance'. To reduce access, they set metal fences to leave three entrances only, where they can request the use of masks and measure temperature. "I think a time of a lot of work for park managers is coming. If we will be more time like this, many activities could be carried out in parks, not in malls, not in museums, but in open spaces." The park manager at La Mexicana is planning in mobilizing high-school students as story tellers for children and look for other innovative solutions that involve safe use of the parks. "People from popular neighbors have had many contagions and deaths. What do you do? To enclose them more and more? We better find a way to make social life in a safe way. When we opened the park we installed large banner with the message 'I missed you', 'Good to see you', 'Welcome'. We also installed mirrors in trees that had a little banner that said 'hug me', with the idea of hugging some other people through the tree and the mirror". The manager of La Mexicana thinks culture is very important for people, but during the pandemic is not possible to enter a closed space to hear the symphonic, but it could be reasonable to attend a quartet of strings in a park. "We should find a way to go to the park and be safe."

\section{Findings}

Before COVID-19 hit, longstanding literatures had established the key role that urban green spaces play in a city's and its residents' resilience. This paper, and the nascent literature it belongs to, illustrates that ensuring an optimal use of the available urban green spaces during a time of social crisis is a matter of governance - i.e. it is a matter that involves actions and efforts to steer society towards beneficial outcomes and away from harmful ones. In this respect, this paper documents the governance challenges posed by COVID-19 and how they were grappled with by the Latin American managers interviewed in the context of this study. In this respect, we summarize our findings as follows:

1. There were different policy challenges at each phase of the pandemic: In April, there was close to a consensus that there was a clear policy objective - keeping people at homeand the choice was in the specific mechanism to accomplish it and in the implementation. A qualitatively different phase was around June, when managers were faced to the decision of how to supply access with minimal risk.

2. A trade-off challenge required different skills: The trade-off challenge during the second phase requires estimation of costs and benefits under uncertainty, deliberation, policy design skills, flexibility to redistribute resources, and capacity to try pilot programs, in addition to implementation skills.

3. Public services sub-types of governance in mid-size cities evaded the trade-off phase: Acknowledging limitations to supply a regulated and safe access, the decision was to accept the costs in terms of physical and mental health of banning access to parks. It is not 
clear this contributed to reduced virus spread, as the crowds moved elsewhere or accessed open parks without supervision or physical barriers, as narrated by our informants. On the other hand, efforts of adapting a service without controlling access might be a case of maladaptation, referred to an increase on vulnerability originated in an inadequate implementation of adaptive measures (Ma et al., 2020).

4. Lack of flexible and innovative approaches is related to lack of human capital and sparse budgets and equipment: Any degree of controlled access requires coordinating users, which entails personnel to apply protocols, communicate rules and spread information during implementation with the crew in charge of regulating access. Typical public services agencies in middle-size cities have enough resources for regular maintenance of the green space. They are not prepared for adjusting the service during a time of crisis.

5. Lack of flexible and innovative approaches is related to the type of training and lack of network of conventional public services approaches: In contrast with managers (of all governance types) that were used to participate in events with the goal of sharing experiences and that belonged to a network in which information and opinions were exchanged, public services managers that were not part of such at network were not acquainted with strategies to try adjustments to their service, but were interested in acquiring such knowledge and have the opportunity of keeping a service that they perceived as increasing in demand as the pandemic went along.

6. Inter-agency governance make up for lack of training and network related capital: In contrast with conventional public services approaches, inter-agency governance has the advantage of using the know-how of different agencies to implement an inter-disciplinary team and come up with innovative responses.

7. Dedicated management type of governance effectiveness depends on leadership: Most managers of urban or metropolitan parks are engaged, well-trained, and take advantage of their national or international network. Political appointees follow a management style very similar to public services approaches, where they are concerned with blame-avoidance and maintenance indicators only.

8. Lack of citizens participation is pervasive independently of the governance type: With important exceptions, most of them at the dedicated management or the inter-agency types, most managers did not find key action where neighbors or non-state participated during the pandemic. This top-down approach contrasts with the feature of stakeholder participation pervasive in the environmental governance literature.

9. Green infrastructure is insufficient: Safety during a pandemic is a function among other factors of the capacity to spread people in space. Some Latin American cities are product of sprawl, and public green spaces were introduced after the fact in a very limited way.Investment in green space of all types is a pending issue in the sub-continent.

10. Social response might be more challenging relative to high-income countries: Accounts of social behavior are of concern, with many countries presenting problems of noncompliance everywhere, including countries regarded as observant of rule-of-law (Brodeur et al. 2020; Nivette et al., 2021; Augeraud-Véron, 2020). Still, reported non-compliance by our interviewees cite more conducts of concern as compared for instance with equivalent non-compliance behavior in European natural parks (McGinlay et al., 2020). 
Our findings point out to a complex research and policy agenda which will not find a 'one-sizefits-all' solution for every type of governance or for any need of all cities. We highlight the relevance of including non-capital cities of different population sizes and income levels, as their challenges are more acute compared to bigger cities in the same countries. Had we focused on the usual sites of study such as capitals or big cities only (Boulton et al. 2018), we would had found few differences with the protocols efforts as those found in natural parks in Europe by McGinlay et al. (2020). These relatively big agencies, in either governance arrangement, have personnel with interdisciplinary (frequently with graduate studies), connected to networks where better practices are shared and with a trajectory in urban policy or environmental issues.

Overall, the key difference between governance types is that the public services approach is more rigid as regard to its objectives where maintenance is the most relevant principle. The reflexive moment mentioned by Kabisch (2015) does not take place. A likely reason is that top management have other endeavours which often are considered of higher priority and receive much more budget and attention. Top managers in these case are not likely to have training related to ecosystems (of either discipline, ecology, enviromental economics, forestry, landscaping), in contrast with the dedicated management types and the inter-agency sub-type.

Focusing on Latin America from a wider perspective and taking into account the case of diversity of cities we will find the specific policies or governance reforms needed to strengthen their capability to provide green spaces to citizens independently of their income. Cortinez-O'Ryan et al. (2020) has pointed out the potential for a deeper inequality originated not only on differential access to green areas and capabilities to afford the lockdown but also in criminal activity - typically, urban parks located in poorer neighborhoods suffer more criminal activity and, therefore, it is possible that poorer residents avoid visiting these green spaces more than usual during the COVID-19 pandemic.

The scarce citizens participation during the pandemic beyond they vocal demand of access to parks is of concern. As discussed by Ryan (2011), urban green spaces represent an urban design resource that must be utilized and nurtured in accordance to a comprehensive concept of green infrastructure, integrating the perceptions and preferences of residents in planning and management strategies. Research on European countries find that residents seem now ready to actively participate in the governance of urban green spaces and have suggestions ready - e.g. "adopt approaches to urban planning which integrate green spaces and tree plantations into new neighborhoods" (Ugolini et al. 2020, p. 7).

The opportunity to develop new policy approaches has great potential. López \& Montero (2018), in the context of sustainable mobility policy design in Mexican cities, have identified stakeholders that they label expert-citizens. These experts-citizens have gained their influence to impact policy design through three key practices: 1) focus on small-scale interventions; 2) their capacity to engage the state and civil society through the use of toned-down language; and 3) a strategic use of media and public opinion tools. They argue that these are a new type of political actor that contributes to new way to design sustainable policies. These expert-citizens can be found in the context of urban green spaces in Latin America, and their expertise is essential to increase governance across Latin America.

\section{$7 \quad$ Public policy implications}

A city's resilience depends on its capability to best take advantage of its urban green spaces. This capability stems from, among other aspects, the governance in place. Findings from the structured interviews reported in this paper suggest that Latin American cities have a long way to go in enhancing governance of urban green spaces, especially in non-capital cities under conventional public 
services governance arrangements.

Regarding governance structures and policy formulation, "one size-does-not-fits-all" — as pointed out by Young (2009) when recommending precaution when coming with simple recommendations that do not take into account that what matters is the fit between a proposed solution and its institutional arrangement. Taking this warning seriously, we recommend that the following topics should be discussed by stakeholders. Our pointers for decision-makers are the following:

1. Choosing a zero-risk is not possible, so discuss the real risk that decisions are implicitly choosing. The bet for strict lockdown was a policy adequate to a specific moment where all efforts were centered on limiting spread. When stringency is relaxed, even if green space managers seek to restrict movement, actual mobility data reveal that citizens use parks, and in the worst case when entrance to parks is banned, they overcrowd in closed businesses or open spaces without regulation. It might be advisable to discuss what do they need in term of protocols, staff, and equipment to provide limited access and monitor compliance.

2. Any project that entails changing citizens mobility patterns should be piloted before scaling up. Only inter-agency and dedicated management types of big cities reported piloting their initiatives to open access when stringency was relaxed. Most managers are not used to documenting activities, analyze what the collected and adjust their plans, due to their training and lack of resources. This health crisis might be the moment to do it in an innovative way. In most big cities there will be universities and schools willing to support systematic data collection and analysis. Regional research centers with programs in public policy, landscaping and some social science schools able to adapt to practical needs may help in conducting the effort.

3. Networking among park managers is key to acquire important lessons that might be useful for their own situation. While policy transfer is a complex activity, the link to different perspectives, knowledge, and plans has been useful for some of our interviewees to develop their protocols and find innovative ways to manage access to parks.

4. Implement available smart cities resources. The use of technology has been proposed as a tool of city managers from at least a couple of decades. COVID-19 crises is the opportunity to put the available technologies to the test. Apps reporting of density in a selection of parks and informing users on availability could be a project that could scale up in the future to include moore advanced features (scheduled activities, reporting infrastructure required repairs, make requests, find the facility with needed amenities, among others).

5. Find partners from public and private sector willing to bring activities currently performed in closed spaces to the open green space. Some activities are already open to the public due to their relevance or the success of pressure groups to keep their economic activity functioning with in-person activities. Some of them could be performed more safely in green areas, which could improve in the value they provide to the public and the public perception of their relevance.

6. Urban policy should not be designed without public green space policy. Major decisions on land use, mobility, housing supply, and others, should incorporate green areas managers to integrate the perspective of green infrastructure or ecosystem services. This is not likely to be in the hands of managers to decide, but on organized stakeholders to include green areas in the urban policy debate and decision-making. 
7. Inventory of equipment, green infrastructure, and its benefits. Investment in green areas will no happen unless it moves up in the priorities of local governments.For this to happen, stakeholders must be able to communicate the relevance or urban green spaces. A first step towards this direction is the inventory of facilities and the documentation of deterioration status. In this respect, the maintenance paradigm will not be enough. It is necessary to transition to a paradigm that includes the concept of ecosystem services so that managers are able to communicate not only description of physical conditions but also their implications in terms of services to the society.

Trying these proposals may not be a choice for some managers - in economics terms, the decisionmaking style is endogenous, and therefore proposing to do something that is not in the portfolio of alternatives due to political restrictions might be out of the question. In these cases, changes may come only from organized participation and mobilization.

\section{Conclusions}

As in other realms, Latin America is a place of contrasts. Complex governance arrangements to manage a system of parks are present in capital cities such as Bogotá, Colombia. There are also emerging institutional inter-agency offices - involving collaboration of state and local governments, and contribution of neighbors - in metropolitan areas such as Guadalajara, Jalisco, in Mexico (second largest city in the country). Also, we can find work-in-progress aiming to create a system of urban green spaces with a ecosystem services perspective - e.g. the city of León, Guanajuato (Mexico) and Guatemala capital. The list of possibilities include innovative private management of public parks as in an affluent area of Mexico City.

Smaller Latin American cities, however, have weaker governance arrangements for their urban green spaces. Particularly, in those cities that are the product of sprawl and have a high percentage of low-income population. In Villanueva, Guatemala, the efforts depend on engaged mid-level staff and top-level leaders intermittently interested on green spaces. Conventional public services managers from mid-size cities are in general under-staffed and under-funded, without networks that allow them to acquire different skills or know lessons from other places. Exceptions to these cases are Cuenca, Ecuador or Salta, Argentina, where green infrastructure is a key feature of the city.

Our findings suggest that maladaptation has occurred across Latin America in terms of usage of urban green spaces. Weak governance of urban green spaces has increased the vulnerability of Latin American societies during the COVID-19 pandemic and, if we do not work towards improving this governance, these societies will be more even more vulnerable during a future societal crisis, related to public health, climate, or other shock.

We found managers with networks with green spaces and park managers from other cities and countries, were more resourceful in finding adaptive responses to solve the trade-off posed by COVID19. Without knowledge of different experiences, managers were more prone to take the lockdown situation as given and keep with their maintenance activities only. Future research on governance of urban green spaces from the perspective of managers should explore the role that manager networks have on the capacity of a city to use their green areas to respond to the current health crisis and future shocks, including climate change, natural disasters, and others.

Other factors that determine the resources available was the leadership at the agency or park level, and the interest shown by political leaders, especially the major. Future work could explore what determine that some leaders opted to invest effort and budget in green areas while other kept with the status quo. It is also key to understand the limited participation of neighbors and other stakeholders 
in Latin America, which has exceptions but overall seems to have a conventional governance approach centered on decision-making by government authorities.

Our findings are relevant for understanding the handling of green areas during the pandemic, which may have policy relevance a few years more, depending of the effect of vaccination, treatments, and the evolution of new virus strains. In addition to the management of a pandemic, future shocks require governance adaptation capabilities that currently are not present in Latin America. More research on governance and more importantly, on the management agencies and the institutional structure that determined them are needed.

\section{Acknowledgements}

This manuscript was produced as part of a multi-disciplinary project - Urban green spaces and compliance with COVID-19 lockdown in Latin American metropolitan areas. The project was prepared in response to UNDP's call Exploring impact and response to the COVID-19 pandemic in Latin America and the Caribbean using mobility data. The authors acknowledge the support of all 16 colleagues involved in the project. In particular, we are thankful with the following people for their help in identifying and contacting stakeholders: Jorge J. Avila-Santamaría, and Luis Romahn. Our deepest gratitude to the stakeholders whose experiences have fed this manuscript. All remaining errors are the sole responsibility of the authors. 


\section{References}

Ambrose-Oji, B., Buijs, A., Ger $\backslash$ Hoházi, E., Mattijssen, T., Száraz, L., van der Jagt, A. P. N., Hansen, R., Rall, E., Andersson, E., \& Kronenberg, J. (2017). Innovative governance for urban green infrastructure: A guide for practitioners. GREEN SURGE. Publication Title: Work Package 6: Innovative Governance for Urban Green Infrastructure Planning and Implementation GREEN SURGE Deliverable 6.3.

Augeraud-Véron, E. (2020). Lifting the COVID-19 lockdown: different scenarios for France. Mathematical Modelling of Natural Phenomena, 15, 40. Publisher: EDP Sciences.

Barona, C. O., Devisscher, T., Dobbs, C., Aguilar, L. O., Baptista, M. D., Navarro, N. M., da Silva Filho, D. F., \& Escobedo, F. J. (2020). Trends in Urban Forestry Research in Latin America \& The Caribbean: A Systematic Literature Review and Synthesis. Urban Forestry \& Urban Greening, 47, 126544. URL: http://www.sciencedirect.com/science/article/pii/ S1618866719303619. doi:10.1016/j.ufug.2019.126544.

Beach, D., \& Pedersen, R. B. (2019). Process-tracing methods: Foundations and guidelines. University of Michigan Press.

Bennett, A., \& Checkel, J. T. (2015). Process Tracing. Cambridge University Press. Google-BooksID: pYkaBQAAQBAJ.

Boulton, C., Dedekorkut-Howes, A., \& Byrne, J. (2018). Factors shaping urban greenspace provision: A systematic review of the literature. Landscape and urban planning, 178, 82-101.

Brodeur, A., Grigoryeva, I., \& Kattan, L. (2020). Stay-at-Home Orders, Social Distancing and Trust. SSRN Scholarly Paper ID 3602410 Social Science Research Network Rochester, NY. URL: https://papers.ssrn. com/abstract=3602410.

Colding, J., Barthel, S., Bendt, P., Snep, R., van der Knaap, W., \& Ernstson, H. (2013). Urban green commons: Insights on urban common property systems. Global Environmental Change, 23, 1039-1051. URL: http://www.sciencedirect.com/science/article/pii/S0959378013000800. doi:10.1016/j.gloenvcha.2013.05.006.

Cortinez-O'Ryan, A., Moran, M. R., Rios, A. P., Anza-Ramirez, C., \& Slovic, A. D. (2020). Could severe mobility and park use restrictions during the covid-19 pandemic aggravate health inequalities? insights and challenges from latin america. Cadernos de Saúde Pública, 36, e00185820.

Eagles, P. F. (2008). Governance models for parks, recreation, and tourism. In Governance models for parks, recreation and tourism. Publisher: Routledge London.

Folke, C., Hahn, T., Olsson, P., \& Norberg, J. (2005). Adaptive governance of social-ecological systems. Annu. Rev. Environ. Resour., 30, 441-473.

Froimson, J. R., Bryan, D. S., Bryan, A. F., \& Zakrison, T. L. (2020). COVID-19, Home Confinement, and the Fallacy of" Safest at Home". American Journal of Public Health, 110, 960-961. Publisher: American Public Health Association.

Geng, D. C., Innes, J., Wu, W., \& Wang, G. (2020). Impacts of covid-19 pandemic on urban park visitation: a global analysis. Journal of forestry research, (pp. 1-15). 
Google LLC (). Google COVID-19 Community Mobility Reports. URL: https://www.google.com/ covid19/mobility/Accessed:October2020.

Hanzl, M. (2020). Urban forms and green infrastructure-the implications for public health during the covid-19 pandemic. Cities 83 Health, (pp. 1-5).

Husky, M. M., Kovess-Masfety, V., \& Swendsen, J. D. (2020). Stress and anxiety among university students in France during Covid-19 mandatory confinement. Comprehensive Psychiatry, 102, 152191. URL: http://www.sciencedirect.com/science/article/pii/ S0010440X2030033X. doi:10.1016/j.comppsych.2020.152191.

Kabisch, N. (2015). Ecosystem service implementation and governance challenges in urban green space planning - The case of Berlin, Germany. Land Use Policy, 42, 557-567. URL: http://www. sciencedirect.com/science/article/pii/S0264837714002002 doi:10.1016/j.landusepol. 2014.09.005.

Kay, A., \& Baker, P. (2015). What can causal process tracing offer to policy studies? A review of the literature. Policy Studies Journal, 43, 1-21. Publisher: Wiley Online Library.

Kleinschroth, F., \& Kowarik, I. (2020). Covid-19 crisis demonstrates the urgent need for urban greenspaces. Frontiers in Ecology and the Environment, 18, 318.

Konijnendijk van Den Bosch, C., Rodbell, P., Salbitano, F., Sayers, K., Villarpando, S., \& Yokohari, M. (2018). The changing governance of urban forests. Unasylva, 69, 37-42.

Lemos, M. C., \& Agrawal, A. (2006). Environmental governance. Annual review of environment and resources, 31.

López, O. S., \& Montero, S. (2018). Expert-citizens: Producing and contesting sustainable mobility policy in mexican cities. Journal of Transport Geography, 67, 137-144.

Lovell, S. T., \& Taylor, J. R. (2013). Supplying urban ecosystem services through multifunctional green infrastructure in the United States. Landscape Ecology, 28, 1447-1463. URL: https://doi. org/10.1007/s10980-013-9912-y. doi:10.1007/s10980-013-9912-y.

López-Bueno, R., Calatayud, J., Andersen, L. L., Balsalobre-Fernández, C., Casaña, J., Casajús, J. A., Smith, L., \& López-Sánchez, G. F. (2020). Immediate Impact of the COVID-19 Confinement on Physical Activity Levels in Spanish Adults. Sustainability, 12, 5708. URL: https://www.mdpi. com/2071-1050/12/14/5708. doi:10.3390/su12145708. Number: 14 Publisher: Multidisciplinary Digital Publishing Institute.

Ma, A. T., Lam, T. W., Cheung, L. T., \& Fok, L. (2020). Protected areas as a space for pandemic disease adaptation: A case of covid-19 in hong kong. Landscape and Urban Planning, 20\%, 103994.

McGinlay, J., Gkoumas, V., Holtvoeth, J., Fuertes, R. F. A., Bazhenova, E., Benzoni, A., Botsch, K., Martel, C. C., Sánchez, C. C., Cervera, I. et al. (2020). The impact of covid-19 on the management of european protected areas and policy implications. Forests, 11, 1214.

Nivette, A., Ribeaud, D., Murray, A., Steinhoff, A., Bechtiger, L., Hepp, U., Shanahan, L., \& Eisner, M. (2021). Non-compliance with COVID-19-related public health measures among young adults in Switzerland: Insights from a longitudinal cohort study. Social Science 85 Medicine, 268, 113370. Publisher: Elsevier. 
Ojeda-Revah, L., Bojorquez, I., \& Osuna, J. C. (2017). How the legal framework for urban parks design affects user satisfaction in a Latin American city. Cities, 69, 12-19. URL: http://www . sciencedirect.com/science/article/pii/S0264275116309726, doi:10.1016/j.cities. 2017. 05.016 .

Ojeda-Revah, L., Ochoa González, Y., \& Vera, L. (2020). Fragmented Urban Greenspace Planning in Major Mexican Municipalities. Journal of Urban Planning and Development, 146, 04020019. Publisher: American Society of Civil Engineers.

Ordóñez, C., Threlfall, C. G., Kendal, D., Hochuli, D. F., Davern, M., Fuller, R. A., van der Ree, R., \& Livesley, S. J. (2019). Urban forest governance and decision-making: A systematic review and synthesis of the perspectives of municipal managers. Landscape and Urban Planning, 189, 166-180. URL: http://www.sciencedirect.com/science/article/pii/ S0169204618310673, doi:10.1016/j.landurbplan.2019.04.020.

Pincetl, S., \& Gearin, E. (2005). The Reinvention of Public Green Space. Urban Geography, 26, 365-384. URL: https://doi.org/10.2747/0272-3638.26.5.365, doi:10.2747/0272-3638.26. 5.365. Publisher: Routledge_eprint: https://doi.org/10.2747/0272-3638.26.5.365.

Piquero, A. R., Riddell, J. R., Bishopp, S. A., Narvey, C., Reid, J. A., \& Piquero, N. L. (2020). Staying Home, Staying Safe? A Short-Term Analysis of COVID-19 on Dallas Domestic Violence. American Journal of Criminal Justice, 45, 601-635. URL: https://doi.org/10.1007/ s12103-020-09531-7, doi:10.1007/s12103-020-09531-7.

Quintanilla, C., \& Ayala, E. (2018). Viviendo los parques. Usos y Costumbres de los mexicanos 2018. Asociación Nacional de Parques y Recreación.

Rigolon, A., Browning, M. H., Lee, K., \& Shin, S. (2018). Access to urban green space in cities of the global south: A systematic literature review. Urban Science, 2, 67.

Ryan, R. L. (2011). The social landscape of planning: Integrating social and perceptual research with spatial planning information. Landscape and Urban Planning, 100, 361-363.

Samuelsson, K., Barthel, S., Colding, J., Macassa, G., \& Giusti, M. (2020). Urban nature as a source of resilience during social distancing amidst the coronavirus pandemic, .

Secretaría de Desarrollo Social (1999). Sistema normativo de equipamiento urbano. Tomo V. Recreación y Deporte.. Secretaría de Desarrollo Social. URL: http://www.inapam.gob.mx/work/ models/SEDESOL/Resource/1592/1/images/recreacion_y_deporte.pdf .

Shoari, N., Ezzati, M., Baumgartner, J., Malacarne, D., \& Fecht, D. (2020). Accessibility and allocation of public parks and gardens in england and wales: A covid-19 social distancing perspective. PloS one, 15, e0241102.

Silverio-Murillo, A., Balmori de la Miyar, J. R., \& Hoehn-Velasco, L. (2020). Families under Confinement: COVID-19, Domestic Violence, and Alcohol Consumption. SSRN Scholarly Paper ID 3688384 Social Science Research Network Rochester, NY. URL: https://papers.ssrn.com/ abstract $=3688384$, doi:10.2139/ssrn.3688384.

Soga, M., Evans, M. J., Tsuchiya, K., \& Fukano, Y. (2020). A room with a green view: the importance of nearby nature for mental health during the covid-19 pandemic. Ecological Applications, (p. e2248). 
Thomas, H., Webster, S., Petherick, A., Phillips, T., \& Kira, B. (2020). Oxford COVID-19 Government Response Tracker. Blavatnik School of Government. https://www. bsg. ox. ac. uk/research/research-projects/coronavirus-government-responsetracker, .

Uchiyama, Y., \& Kohsaka, R. (2020). Access and use of green areas during the covid-19 pandemic: Green infrastructure management in the "new normal". Sustainability, 12, 9842.

Ugolini, F., Massetti, L., Calaza-Martínez, P., Cariñanos, P., Dobbs, C., Ostoić, S. K., Marin, A. M., Pearlmutter, D., Saaroni, H., Šaulienè, I. et al. (2020). Effects of the covid-19 pandemic on the use and perceptions of urban green space: An international exploratory study. Urban forestry 86 urban greening, 56, 126888.

United Nations (2020). Sustainable development goals report 2020. URL: https://sdgs.un.org/ publications/sustainable-development-goals-report-2020-24686 Accessed December31, 2020.

Venter, Z., Barton, D., Figari, H., Nowell, M. et al. (2020). Urban nature in a time of crisis: recreational use of green space increases during the covid-19 outbreak in oslo, norway. Environmental Research Letters, 15.

Wang, G., Zhang, Y., Zhao, J., Zhang, J., \& Jiang, F. (2020). Mitigate the effects of home confinement on children during the COVID-19 outbreak. The Lancet, 395, 945-947. URL: https://www.thelancet.com/journals/lancet/article/PIIS0140-6736(20)30547-X/ abstract. doi:10.1016/S0140-6736(20)30547-X. Publisher: Elsevier.

World Health Organization (2020). Strengthening and adjusting public health measures throughout the COVID-19 transition phases. Policy considerations for the WHO European Region, 24 April 2020 (produced by WHO/Europe). URL: https://www.euro.who.int/en/health-topics/health-emergencies/ coronavirus-covid-19/publications-and-technical-guidance/2020/ strengthening-and-adjusting-public-health-measures-throughout-the-covid-19-transi.tion-ph -policy-considerations-for-the-who-european-region, -24-april-2020-produced-by-whoeurope.

Xie, J., Luo, S., Furuya, K., \& Sun, D. (2020a). Urban parks as green buffers during the covid-19 pandemic. Sustainability, 12, 6751.

Xie, X., Xue, Q., Zhou, Y., Zhu, K., Liu, Q., Zhang, J., \& Song, R. (2020b). Mental Health Status Among Children in Home Confinement During the Coronavirus Disease 2019 Outbreak in Hubei Province, China. JAMA Pediatrics, 174, 898. URL: https://jamanetwork.com/journals/ jamapediatrics/fullarticle/2765196. doi:10.1001/jamapediatrics.2020.1619.

Young, O. R. (2009). Governance for sustainable development in a world of rising interdependencies. Governance for the Environment. New perspectives, (pp. 12-40). Publisher: Cambridge University Press: Cambridge.

Zhu, J., \& Xu, C. (2020). Sina microblog sentiment in beijing city parks as measure of demand for urban green space during the covid-19. Urban Forestry $\&$ Urban Greening, (p. 126913).

Zingraff-Hamed, A., Hüesker, F., Lupp, G., Begg, C., Huang, J., Oen, A., Vojinovic, Z., Kuhlicke, C., \& Pauleit, S. (2020). Stakeholder Mapping to Co-Create Nature-Based Solutions: Who Is on Board? Sustainability, 12, 8625. URL: https://www.mdpi.com/2071-1050/12/20/8625. doi:10. 3390/su12208625. Number: 20 Publisher: Multidisciplinary Digital Publishing Institute. 


\section{Tables}


Table 1: Interviews

\begin{tabular}{|c|c|c|c|c|c|}
\hline Country & Respondent & Agency & Urban green space & Location & Date of interview \\
\hline Argentina & $\begin{array}{l}\text { Consultant of public } \\
\text { spaces for the municipal- } \\
\text { ity }\end{array}$ & $\begin{array}{l}\text { Municipality of } \\
\text { Salta }\end{array}$ & $\begin{array}{l}\text { Parks of the municipality } \\
\text { of Salta }\end{array}$ & Salta, Argentina & November 10 and 12,2020 \\
\hline Colombia & Park manager & $\begin{array}{l}\text { Instituto Distrital } \\
\text { de Recreación y } \\
\text { Deporte (IDRD) }\end{array}$ & $\begin{array}{l}5,256 \text { parks (including } \\
\text { pocket, neighboorhood, } \\
\text { and zonal parks, plus } \\
18 \text { metropolitan and one } \\
\text { regional park). }\end{array}$ & Bogotá, Colombia & $\begin{array}{l}\text { December } 14,2020 \text { (they } \\
\text { sent a written response to } \\
\text { a questionnaire). }\end{array}$ \\
\hline Ecuador & Entrepreneur & $\begin{array}{l}\text { State owned hydro- } \\
\text { electrics }\end{array}$ & $\begin{array}{l}\text { Ecological corridors at } \\
\text { hydroelectric } \\
\text { Project at historical } \\
\text { downtown of Quito }\end{array}$ & Quito, Ecuador & $\begin{array}{lll}\begin{array}{l}\text { September } \\
\text { group) }\end{array} & 14 & \text { (focal }\end{array}$ \\
\hline Guatemala & Chief of Department & Public Services & $\begin{array}{l}415 \text { parks in Guatemala } \\
\text { (they attend a fraction of } \\
\text { them) }\end{array}$ & Guatemala, Guatemala & October 7,2020 \\
\hline Guatemala & Director & $\begin{array}{l}\text { Fundación Calme- } \\
\text { cac (not-for-profit } \\
\text { NGO) }\end{array}$ & $\begin{array}{l}\text { Parque Ciudad Nueva en } \\
\text { Guatemala }\end{array}$ & Guatemala, Guatemala & October 5, 2020 \\
\hline Guatemala & $\begin{array}{l}\text { Chief of Department of } \\
\text { Social Activities } \\
\text { Chief of Department }\end{array}$ & $\begin{array}{l}\text { Public Services of } \\
\text { the municipality } \\
\text { of Villa Nueva } \\
\text { (Department of } \\
\text { Guatemala) }\end{array}$ & 109 parks & Villanueva, Guatemala & October 19,2020 \\
\hline Mexico & Director of Park & $\begin{array}{l}\text { Asociación } r \\
\text { Colonos de } \\
\text { Fe }\end{array}$ & La Mexicana & $\begin{array}{l}\text { Santa Fe, Mexico City, } \\
\text { Mexico }\end{array}$ & $\begin{array}{l}\text { September } \\
\text { group) }\end{array}$ \\
\hline \multirow[t]{2}{*}{ Mexico } & $\begin{array}{l}\text { Head of Ecological } \\
\text { Restoration Department } \\
\text { Head of Social activities } \\
\text { Department }\end{array}$ & $\begin{array}{l}\text { Agencia Metropoli- } \\
\text { tana de Bosques de } \\
\text { Guadalajara }\end{array}$ & Metropolitan & $\begin{array}{lc}\text { Metropolitan } & \text { Area of } \\
\text { Guadalajara, } & \text { Jalisco, } \\
\text { Mexico } & \end{array}$ & $\begin{array}{l}\text { September } 10,2020 \text { (in- } \\
\text { dividual interview with } \\
\text { Head of Restoration De- } \\
\text { partment) }\end{array}$ \\
\hline & & & & & $\begin{array}{l}\text { September } 14 \quad \text { (focal } \\
\text { group) }\end{array}$ \\
\hline Mexico & $\begin{array}{l}\text { General Director of a } \\
\text { metropolitan agency }\end{array}$ & $\begin{array}{l}\text { Instituto } \\
\text { Metropolitano } \\
\text { de Planeación } \\
\text { (IMEPLAN) }\end{array}$ & $\mathrm{N} / \mathrm{A}$ & $\begin{array}{lc}\text { Metropolitan } & \text { Area of } \\
\text { Guadalajara, } & \text { Jalisco, } \\
\text { Mexico } & \end{array}$ & January 26,2021 \\
\hline
\end{tabular}


Table 1: Interviews

\begin{tabular}{|c|c|c|c|c|c|}
\hline Country & Respondent & Agency & Urban green space & Location & Date of interview \\
\hline Mexico & Director of Park & Parque Tamayo & Parque Tamayo & $\begin{array}{l}\text { Municipality of San Pedro } \\
\text { Garza, Nuevo Leon, Mex- } \\
\text { ico }\end{array}$ & $\begin{array}{lll}\begin{array}{l}\text { September } \\
\text { group) }\end{array} & 14 & \text { (focal } \\
\end{array}$ \\
\hline Mexico & $\begin{array}{l}\text { Director of Centro de Ed- } \\
\text { ucación Ambiental Lan- } \\
\text { deros } \\
\text { Director of Culture and } \\
\text { Environmental Education } \\
\text { of the Center }\end{array}$ & $\begin{array}{l}\text { Ministry of Water } \\
\text { and Natural Re- } \\
\text { sources }\end{array}$ & $\begin{array}{l}\text { Centro de Educación Am- } \\
\text { biental Rodolfo Landeros }\end{array}$ & $\begin{array}{ll}\text { Aguascalientes, } & \text { Aguas- } \\
\text { calientes, Mexico } & \end{array}$ & October 13,2020 (in situ) \\
\hline Mexico & $\begin{array}{l}\text { Secretary of General Ser- } \\
\text { vices of Zacatecas, Zacate- } \\
\text { cas. }\end{array}$ & $\begin{array}{l}\text { Secretary of Public } \\
\text { Services of Zacate- } \\
\text { cas, Zacatecas. }\end{array}$ & $\begin{array}{l}50 \text { parks and public spaces } \\
\text { (30 urban parks) }\end{array}$ & $\begin{array}{l}\text { Zacatecas, Zacatecas, } \\
\text { Mexico }\end{array}$ & October 8, 2020 \\
\hline Mexico & $\begin{array}{l}\text { Secretary of Public Ser- } \\
\text { vices of Jesús María, } \\
\text { Aguascalientes. }\end{array}$ & $\begin{array}{l}\text { Secretary of Public } \\
\text { Services of Jesús } \\
\text { María, Aguas- } \\
\text { calientes. }\end{array}$ & 56 parks and public spaces & $\begin{array}{l}\text { Jesús María, Aguas- } \\
\text { calientes, Mexico }\end{array}$ & September 22, 2020 \\
\hline Mexico & Chief of Department & $\begin{array}{l}\text { Director of Natural } \\
\text { Resources, León, } \\
\text { Guanajuato. }\end{array}$ & 82 parks & $\begin{array}{l}\text { León, Guanajuato, Mex- } \\
\text { ico }\end{array}$ & September 28, 2020 \\
\hline Mexico & Director & Jardines de México & $\begin{array}{l}\text { Recreational park Jar- } \\
\text { dines de México }\end{array}$ & $\begin{array}{l}\text { Cuernavaca, } \\
\text { Mexico }\end{array}$ & September 28, 2020 \\
\hline Perú & $\begin{array}{l}\text { Architect in a real state } \\
\text { development company }\end{array}$ & $\begin{array}{l}\text { Developer of pri- } \\
\text { vate parks within } \\
\text { gated housing }\end{array}$ & $\begin{array}{l}\text { Private parks at gated } \\
\text { communities in Piura, } \\
\text { Peru }\end{array}$ & Piura, Peru & September 28, 2020 \\
\hline
\end{tabular}


Table 2: Governance of Urban Green Areas in Latin America Typology

\begin{tabular}{|c|c|c|}
\hline Type & Sub-Types/Description & Cases \\
\hline $\begin{array}{l}\text { Municipality Agency } \\
\text { A municipality agency is in charge of } \\
\text { managing public urban green areas. }\end{array}$ & $\begin{array}{l}\text { Public Services This is the most } \\
\text { frequent governance model, where } \\
\text { an office within Public Services Di- } \\
\text { rection or Secretariat is in charge } \\
\text { of maintaining and operating parks } \\
\text { and other urban green areas, such as } \\
\text { medians, gardens, roundabouts and } \\
\text { others. } \\
\text { Inter-agency An office (for in- } \\
\text { stance, Sports, Youth, or Environ- } \\
\text { mental Resources) that is in charge } \\
\text { of the strategic decisions related } \\
\text { to urban green spaces - such as } \\
\text { landscaping based on a vegetation } \\
\text { palette or defining the activities al- } \\
\text { lowed within the urban green space. } \\
\text { Importantly, a different municipal- } \\
\text { ity office is in charge of maintenance } \\
\text { and some operation decisions. }\end{array}$ & $\begin{array}{l}\text { Argentina } \\
\text { City of Salta } \\
\text { Colombia } \\
\text { Bogotá (Instituto Distrital de } \\
\text { Recreación y Deporte) } \\
\text { Guatemala } \\
\text { Municipality of Guatemala } \\
\text { Municipality of Villanueva } \\
\text { Mexico } \\
\text { Jesús María } \\
\text { Zacatecas } \\
\text { León, Guanajuato (Inter-Agency) } \\
\text { Ecuador } \\
\text { Cuenca }\end{array}$ \\
\hline $\begin{array}{l}\text { Dedicated management } \\
\text { Characterized by the existence of an } \\
\text { entity (frequently organically linked } \\
\text { to a state or municipal government) } \\
\text { in charge of planning, maintaining } \\
\text { and operating a single urban park. }\end{array}$ & $\begin{array}{l}\text { Public Management A decentral- } \\
\text { ized office, under state or munic- } \\
\text { ipal supervision, is in charge of } \\
\text { Metropolitan parks or long linear } \\
\text { parks. } \\
\text { Private Management A private } \\
\text { entity (e.g. neighbourhood associa- } \\
\text { tion) manages a public urban park. }\end{array}$ & $\begin{array}{l}\text { Ecuador } \\
\text { Quito } \\
\text { Ecological corridors at hydroelectric } \\
\text { Project at historical downtown of } \\
\text { Quito } \\
\text { Mexico } \\
\text { Park Tamayo in San Pedro Garza } \\
\text { Public park La Mexicana in Mexico } \\
\text { City (private management) } \\
\text { Aguascalientes (Centro de Edu- } \\
\text { cación Ambiental Landeros) }\end{array}$ \\
\hline $\begin{array}{l}\text { Polycentric management } \\
\text { Planning, operation and mainte- } \\
\text { nance of a network of parks are re- } \\
\text { sponsibilities shared by agencies of } \\
\text { different levels of government. }\end{array}$ & $\begin{array}{l}\text { There are many combinations in } \\
\text { which local and state level govern- } \\
\text { ments collaborate. }\end{array}$ & $\begin{array}{l}\text { Mexico } \\
\text { Urban Parks managed by Agencia } \\
\text { Metropolitana de Bosques }\end{array}$ \\
\hline $\begin{array}{l}\text { Not-for-Profit usufruct } \\
\text { A NGO is in charge of managing and } \\
\text { getting funding for a park under the } \\
\text { figure of usufruct }\end{array}$ & $\begin{array}{l}\text { There are many combinations de- } \\
\text { pending on the conditions of the } \\
\text { usufruct covenant. }\end{array}$ & $\begin{array}{l}\text { Guatemala } \\
\text { Parque Ciudad Nueva in Guatemala }\end{array}$ \\
\hline
\end{tabular}




\section{Figures}

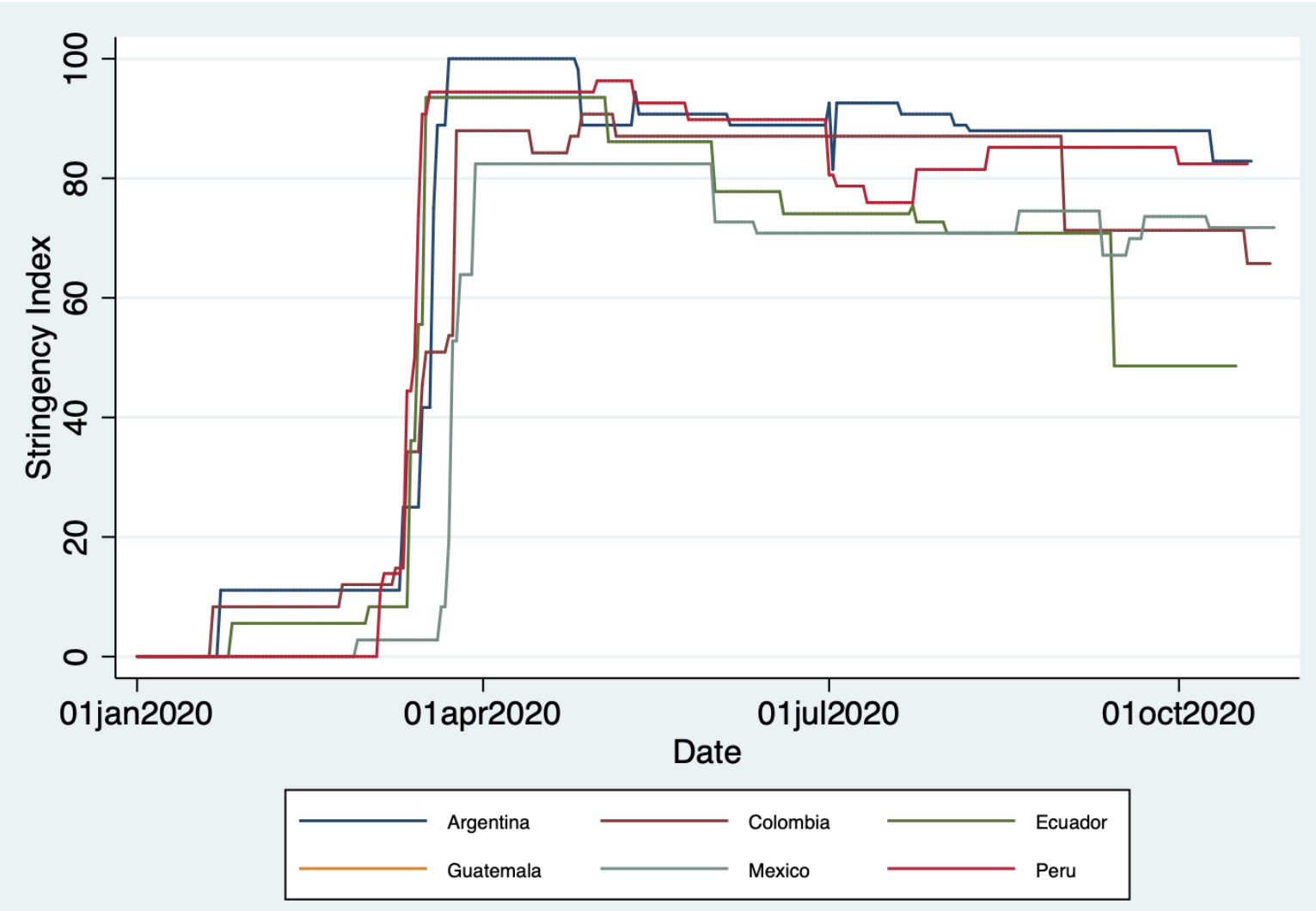

Source: Data from Oxford Tracker Data

Figure 1: Stringency Index in Countries of Study 


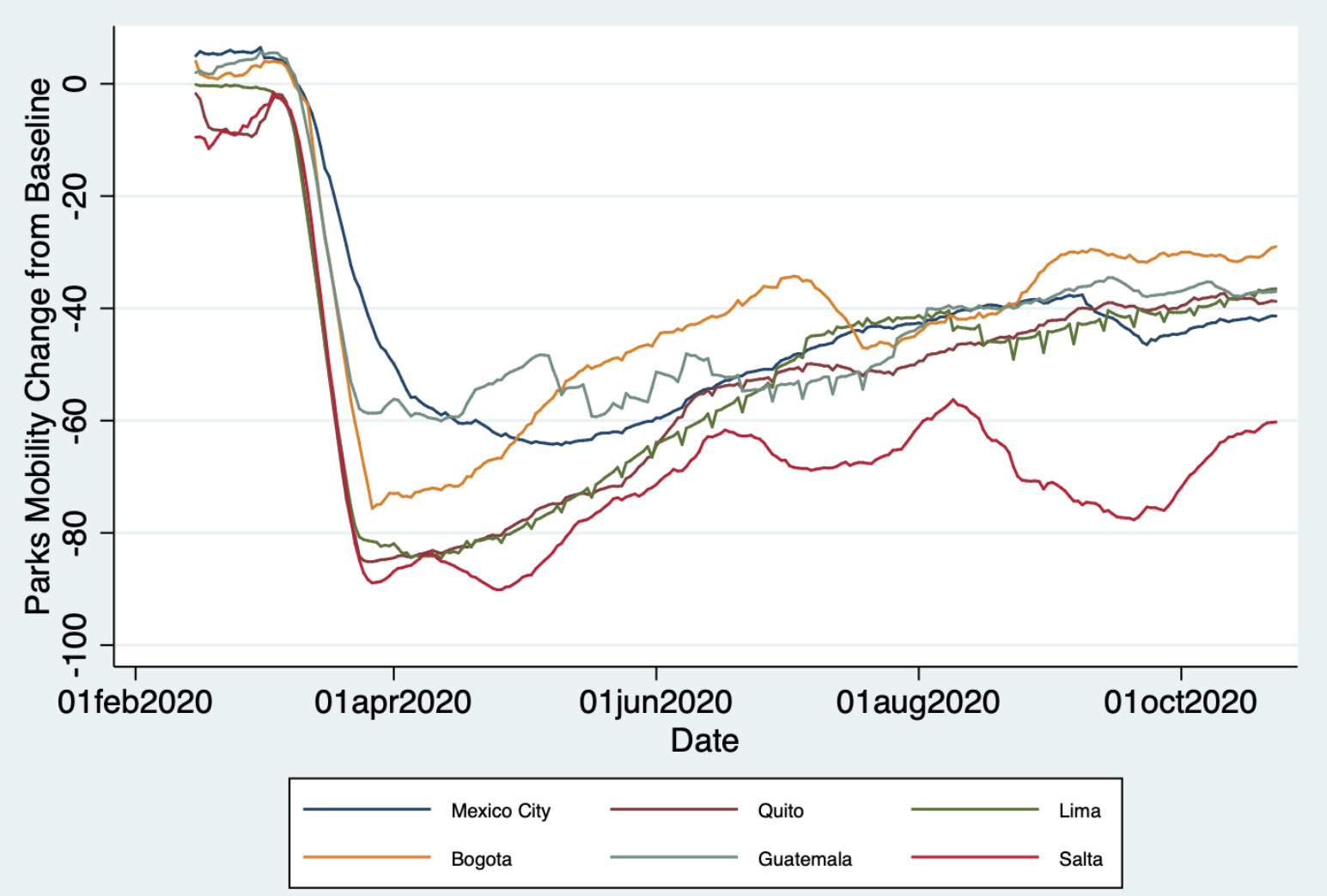

Source: Stringency Index by Oxford Tracker Data; Parks mobility by Google Mobility Reports

Figure 2: Mobility in parks during the COVID-19 pandemic (Seven days moving average) 


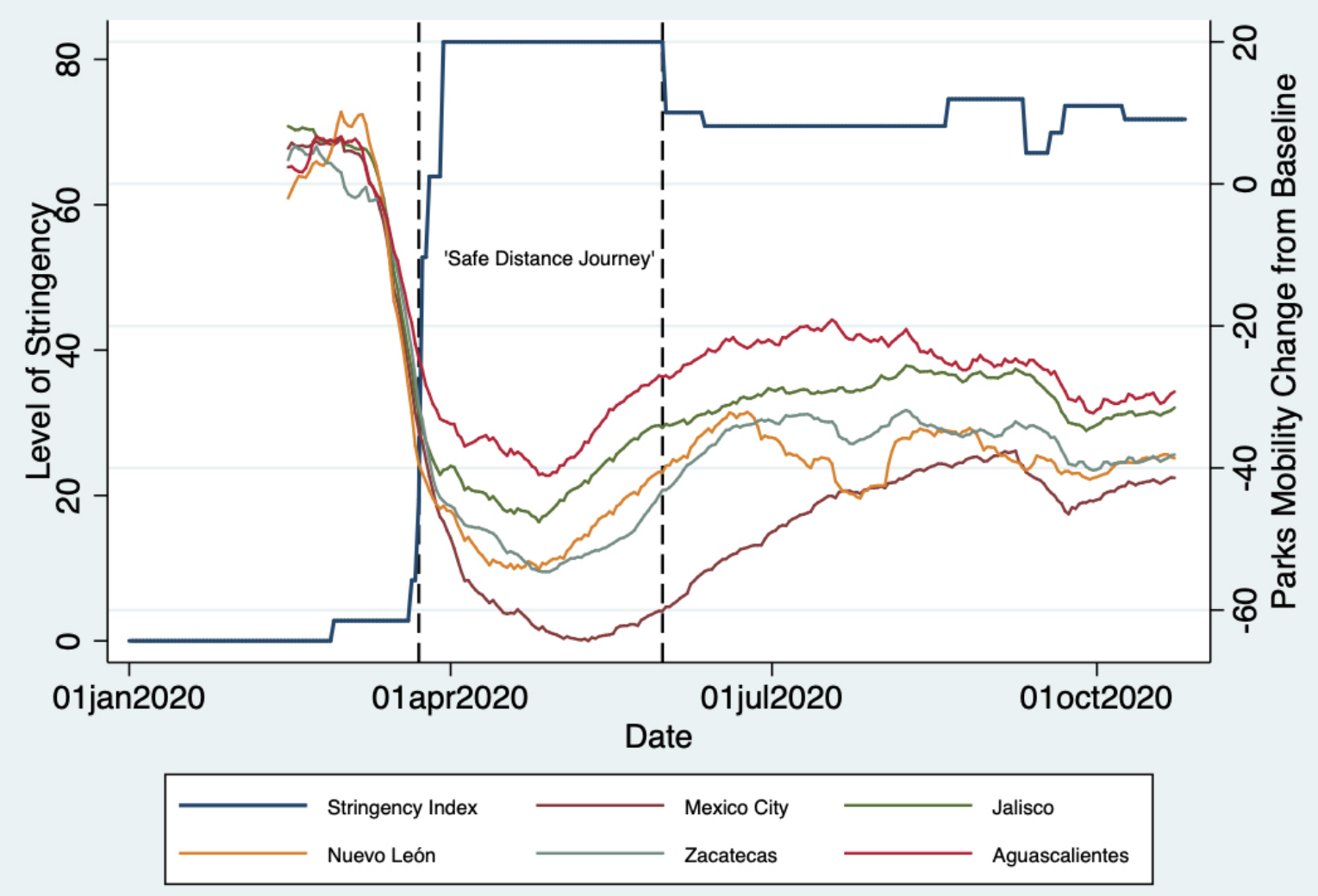

Source: Stringency Index by Oxford Tracker Data; Parks mobility by Google Mobility Reports

Figure 3: Stringency in Mexico and mobility in parks (Seven days moving average) 


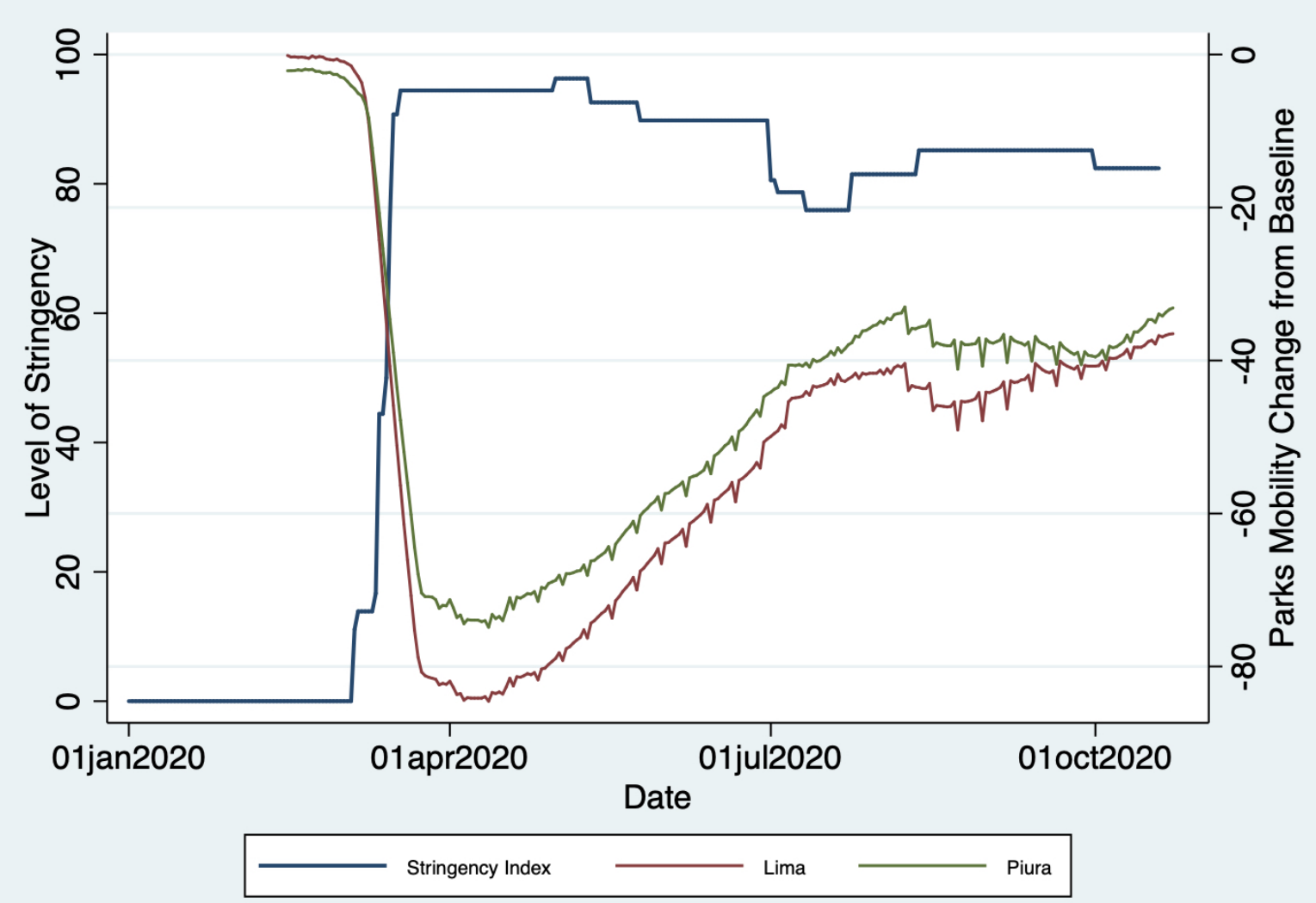

Source: Stringency Index by Oxford Tracker Data; Parks mobility by Google Mobility Reports

Figure 4: Stringency in Peru and mobility in parks (Seven-days moving average) 